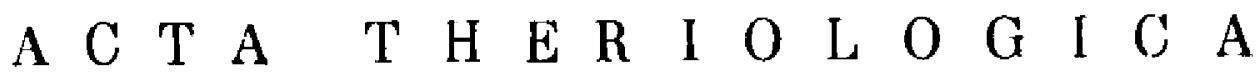 \\ VOL. XIII, 32: $511-551$. \\ BIAEOWIEŹA \\ 28.XII.1968
}

\author{
Krzysztof S W I E Ż Y N S K I
}

\section{The Male Reproductive Organs of the European Bison}

\author{
Bisoniana XXXVIII
}

[With 3 Figs., 10 Tables and Plates $\mathbf{X V - X I X ]}$

\begin{abstract}
The dimensions and weight of the testicles, and also their shape and position, were described on the basis of dissections of the cadavers of 20 European bison of different age. Corresponding data were ascertained for the epididymis, ductus deferens, genital accessory glands, urethra and penis. Uterus masctulinus was found to occur in male European bison. No distinct relation was found between the degree of development of the latter and the formation of any of the other genital organs and the reproductive capacity of the males of this species. A description is given of the structure of the scrotum, prepuce and of muscles topographically and functionally connected with the genital organs. In comparison with domestic cattle the testicles of adult European bison are more spherical and their mean weight is smaller. The epididymis has a strongly marked, wide head and thickened tail set caudad. Among the genital accessory glands the bulbourethral glands differ as to position, and are smaller than those in domestic bulls. The scrotum in the European bison is situated more to the back, is relatively short, with faintly defined collum. The left part of the scrotum, together with the testicle, protrudes slightly forwards. The sigmoid flexure of the penis is only faintly marked.
\end{abstract}

1. Introduction +

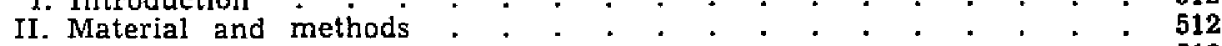

III. The testicles - $\cdot$. j - . 513

IV. The epididymis, the ductus deferens and spermatic cord $\cdot .55$

V. The scrotum and covering structures of the testicles, the epididymis and the spermatic cords.

VI. The genital accessory glands

1. Ampullae ductuum deferentium . . . . . . . . . . 521

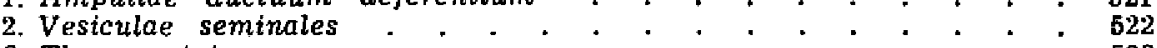

3. The prostate . . . . . . . . . . . . . . . . 523

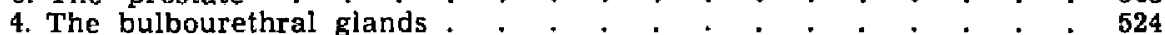

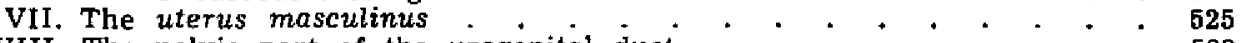

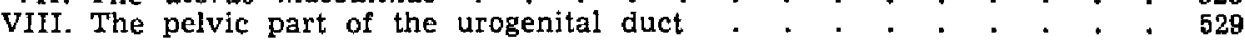

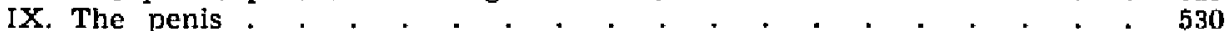

1. Corpus penis . . . . . . . . + . . . . . . 530

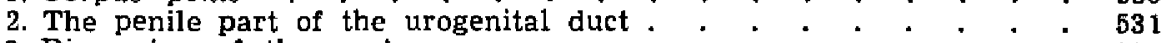

3. Dimension of the penis.$+5 .+5$

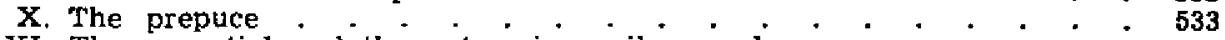

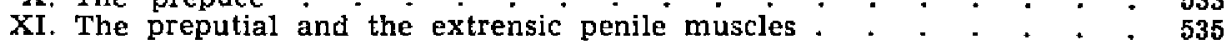


XII. Results and discussion .

1. Testicles, epididymis and scrotum : . . . . . . . . . 537

2. The genital accessory glands . . . . . . . . . . . . . . . 541

3. Uterus masculinus. . . . . . . . . . . . . . . 542

4. Penis . . . . . . . . . . . . . . . . . . 545

5. The preputial and extrensic penile muscle: . . . . . . . 546

References . . . . . . . . . . . . . . . . . . . 547

Streszczenie

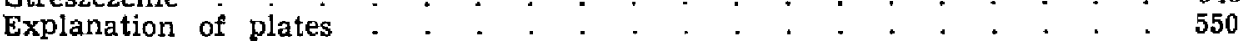

\section{INTRODUC'TION}

Literature dealing with the anatomy of the male genital organs of the European bison is scanty. From the historical aspect mention must first be made of the work by Bojan u (1827), who gives some remarks on the appearance of the scrotum and testicles.

$O$ we $n$ (1848) in describing the structure of the internal organs of the male European bison limits himself to the laconic statement w...the scrotum and testes were much smaller than in the young domestic bulls of the same age; the serotum is rugous, senile, not pendulous, with a constricted neck as in Bos taurusa. MI ii Ile r (1852) in his study $\gg$ Remarks on European bison describes in the section devoted to anatomy the testicles, vas deferens, seminal vesicules and uterus masculinus of sunusual structure not hitherto described in any species.. In further discussion on the subject of this organ the author reached the conclusion that it was a case not exhibiting abnormal characteristics.

K r öl I ing (1930) had at his disposal part of the genital organs of a male bison which died in Schönbrunn Zoo. Using histological slides made from the organs of the pelvic part of the male genital system, he described in detail the structure of the terminal portions of the deferens ducts, vesiculae seminales and uterus masculius, which occurred in this individual also. Remarks on the appearance of the external genitalia of the European bison are also to be found in the monograph by Wroblewski (1927).

The aim of the present study is to elaborate as comprehensively as possible the anatomy of the male reproductive organs of the European bison. The author hopes that the results of his investigations, in addition to their value as a source of information on the morphology, may also be of use in other studies on the species, such as its physiology, intergeneric hybrids or breeding operations.

\section{MATERIAL AND METHODS}

The material used consisted of the cadavers of 20 bison which reached the Research Centre of Anatomy of the European bison during the period from 19501966. These were purebred European bison varying in age from one day to seventeen years of age.

In order to give a fuller description of the animals dissected some of the external body dimensions have been included in the details of material, thus making it possible to compare the size of the various individuals (Table 1). Measurements were made on cadavers which had not yet been fixed. The measurement points and way in which the measurements were made, and terms used for the measurements, were the same as those hitherto used in the Warsaw Centre ( $\mathrm{P} i$ e $\mathrm{k}$ os $\dot{s}$ et al., 1958).

Linear measurements were made by means of a soft surveying tape measure, ruler with millimctre scale, compasses, nonius and micrometer. The measurement 
points of the various organs are illustrated in Fig. 1. Where necessary the way in which the measurement was made is described together with the description of the appropriate organ.

The weight of the organs was found on a laboratory balance.

As the degree of bleeding or its absence and the method used for fixing were of necessity different, absolute figures for measurements and weights of organs should be treated as approximate data.

Some dissections were made from fresh material, but the great majority from fixed material. Fixing was carried out by storing the isolated organs in $7-8 \%$ formalin water solution or by intraarterial injection of the whole body by the method used in the Centre (Pilars k et al., 1967).

Table 1.

Material examined.

\begin{tabular}{|c|c|c|c|c|c|c|c|c|c|}
\hline \multirow{2}{*}{ No. } & \multirow{2}{*}{ Name } & \multirow{2}{*}{$\begin{array}{l}\text { No. of } \\
\text { pedigree } \\
\text { book }\end{array}$} & \multicolumn{3}{|c|}{ Age } & \multicolumn{4}{|c|}{$\begin{array}{ll} & \text { Body } \\
\text { external measurements }\end{array}$} \\
\hline & & & Years & Months & Days & A & $\mathrm{D}$ & E & $\mathbf{F}$ \\
\hline 1 & Pos & $* *$ & - & - & - & 116 & - & 45 & 53 \\
\hline 2 & Pub & ** & - & - & 1 & 114 & 86 & 45 & 62 \\
\hline 3 & Pom & 1364 & - & - & 7 & $107^{*}$ & - & $44^{*}$ & $75^{*}$ \\
\hline 4 & Plakat & $* *$ & - & 1 & 10 & 132 & 104 & 67 & 89 \\
\hline 5 & Pustybór & 906 & - & 10 & 17 & 183 & 135 & 105 & 115 \\
\hline 6 & Poronin & 1459 & 2 & - & 8 & 212 & 156 & 95 & 137 \\
\hline 7 & Putnar & 1569 & 3 & 3 & 24 & 247 & 171 & 128 & 178 \\
\hline 8 & Puck & 1151 & 4 & - & 22 & 247 & 179 & 112 & 162 \\
\hline 9 & Puzor & 1208 & 5 & 7 & 3 & 275 & 185 & 130 & 185 \\
\hline 10 & Pug II & 1087 & 6 & 1 & 25 & $280^{*}$ & $184^{*}$ & $125^{*}$ & $189^{*}$ \\
\hline 11 & Pozew & 1082 & 6 & 4 & 13 & 250 & 170 & 120 & 190 \\
\hline 12 & Puer & 934 & 7 & - & 27 & - & - & - & - \\
\hline 13 & Pustelnik & 694 & 8 & 4 & 21 & 269 & 170 & - & - \\
\hline 14 & Polamiec & 572 & 9 & 2 & 5 & 260 & 183 & 125 & - \\
\hline 15 & Pokorny & 1077 & 9 & 1 & 26 & 283 & 177 & 133 & 220 \\
\hline 16 & Posusz & 984 & 10 & 1 & 12 & 273 & 202 & 129 & 206 \\
\hline 17 & Pluszez & 785 & 10 & 5 & 3 & 248 & - & - & - \\
\hline 18 & Plamiec & 789 & 14 & 4 & 18 & 262 & 172 & 126 & 180 \\
\hline 19 & Pomruk & 816 & 14 & 7 & - & - & - & - & - \\
\hline 20 & Plato & 575 & 17 & 3 & 28 & 280 & 190 & 135 & 160 \\
\hline
\end{tabular}

* - Measurement made after removing skin; ** - The pedigree books of European bison born in these years have not yet been published.

Where the state of the cadavers, on account either of advanced decomposition or damage caused by anatomical and pathological dissection, prevented their being used as a whole, only certain of the organs were taken for detailed examination.

The ierm used in this study sadult bison « refers, in accordance with the results of investigations made by $\mathrm{Roskosz} \& \mathrm{Empel}$ (1963), to individuals over 5 years old.

\section{THE TESTICLES}

The testicles of the male European bison are oval in shape. The long axis of the testicles in adult animals is situated decidedly vertically. The 
medial surface is flatter than the lateral. The epididymis in the cadaver is adherent to the caudolateral surface of the testes.

In two calves, one one-day old and one seven-days old, the testicles were situated close to the external inguinal ring, the long axis being almost horizontal. The thread-like ligamentum inguinale testis, about
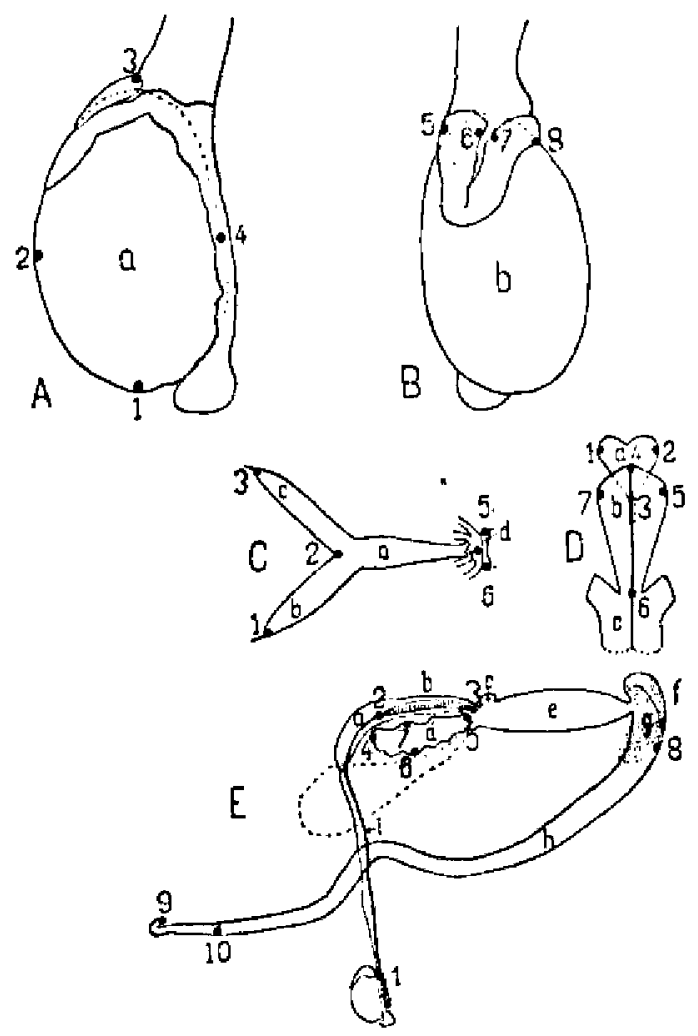

Fig. 1. Plan of distribution of measuring points.

A, B - testicles; a - lateral surface; b - cranial surface. 1 - 3 length of testicle; $2-4$ breadth of testicle; $5-6$ breadth of proximal root of caput epididymidis; $7-8$ breadth of distal root of caput epididymidis; $5-8$ breadth of base of caput epididymidis.

$c$ - uterus masculinus (dorsal surface); a - undivided part; b, c - left and right horn; $\mathrm{d}-$ corpus prostatae. $1-2$ length of left horn; $2-3$ length of right horn; $3-4$ length of undivided part; $5-6$ transverse measurement of prostate. $D$ - bulbus urethrae and bulbourethral glands (caudal surface): a - bulbourethral glands; b - bulbus urethrae; c - radix penis. 1 - 2 tranverse measurement of bulbourethral glands; $1-3$ longitudinal measurement of bulbourethral gland; $4-6$ length of bulbus urethrae; $5-7$ breadth of bulbus urethrae in widest place.

$\mathrm{E}-$ male genital organs (seen from left side); a - uterus masculinus; b ampulla ductus deferentis; c - prostate; d - vesicula seminalis; e - pars pelvina urethrae; $\mathrm{f}-m$. bulbocavernosus; $\mathrm{g}-m$. ischiocavernosus; $h-$ penis; i ductus deferens. 1 - 3 length of ductus deferens; $2-3$ length of ampulla ductus deferentis; $4-5$ longitudinal measurement of vesicula seminalis; $6-7$ transverse measurement of vesicula seminalis; $8-9$ total length of penis; $9-10$ leneth pars preputialis penis. 
$3 \mathrm{~cm}$. long, runs from the tail of the epididymis of each of the testicles to the caudoventral inner surface of the scrotum wall. In "Plakat", one month old, the long axis of the testicles ran obliquely. Ligamenta inguinalia testiculorum were far broader than in the previous testicles.

Table 2.

Measurements and weight of testicles according to age groups (cf. table 1).

\begin{tabular}{|c|c|c|c|c|c|c|c|}
\hline \multirow{4}{*}{ No. } & \multirow{4}{*}{ Name } & \multicolumn{4}{|c|}{ Measurement in millimetres } & \multirow{2}{*}{\multicolumn{2}{|c|}{$\begin{array}{c}\text { Weight in grammes } \\
\text { Testicle }\end{array}$}} \\
\hline & & \multicolumn{4}{|c|}{ Testicle } & & \\
\hline & & \multicolumn{2}{|c|}{ Right } & \multicolumn{2}{|c|}{ Left } & \multirow{2}{*}{ Right } & \multirow{2}{*}{ Left } \\
\hline & & Length & Breadth & Length & Breadth & & \\
\hline $\begin{array}{l}1 \\
2 \\
3\end{array}$ & $\begin{array}{l}\text { Pos } \\
\text { Pub } \\
\text { Pom }\end{array}$ & $\begin{array}{l}23 \\
26 \\
29\end{array}$ & $\begin{array}{l}11 \\
15 \\
14\end{array}$ & $\begin{array}{l}24 \\
25 \\
28\end{array}$ & $\begin{array}{l}12 \\
16 \\
15\end{array}$ & $\begin{array}{l}1.65 \\
2.00 \\
3.00\end{array}$ & $\begin{array}{l}1.75 \\
1.60 \\
3.00\end{array}$ \\
\hline & Mean & 26 & 13 & 26 & 18 & 2.17 & 2,07 \\
\hline $\begin{array}{l}4 \\
5\end{array}$ & $\begin{array}{l}\text { Plakat } \\
\text { Pustybór }\end{array}$ & $\begin{array}{l}34 \\
38\end{array}$ & $\begin{array}{l}14 \\
19\end{array}$ & $\begin{array}{l}34 \\
36\end{array}$ & $\begin{array}{l}16 \\
18\end{array}$ & $\begin{array}{l}3.10 \\
8.00\end{array}$ & $\begin{array}{l}3.50 \\
7.60\end{array}$ \\
\hline & Mean & 36 & 17 & 35 & 17 & 5.55 & 5.60 \\
\hline $\begin{array}{l}6 \\
7\end{array}$ & $\begin{array}{l}\text { Poronin } \\
\text { Putnar }\end{array}$ & $\begin{array}{l}86 \\
91\end{array}$ & $\begin{array}{l}53 \\
60\end{array}$ & $\begin{array}{l}92 \\
90\end{array}$ & $\begin{array}{l}62 \\
44\end{array}$ & $\begin{array}{l}120.00 \\
128.00\end{array}$ & $\begin{array}{l}106.00 \\
100.00\end{array}$ \\
\hline & Mean & 89 & 51 & 91 & 53 & 124.00 & 103.00 \\
\hline $\begin{array}{r}8 \\
9 \\
10 \\
11 \\
12 \\
13 \\
14 \\
15 \\
16 \\
17\end{array}$ & $\begin{array}{l}\text { Pug II } \\
\text { Pozew } \\
\text { Puer } \\
\text { Pustelnik } \\
\text { Polamiec } \\
\text { Pokorny } \\
\text { Posusz } \\
\text { Pluszcz } \\
\text { Plamiec } \\
\text { Plato }\end{array}$ & $\begin{array}{r}96 \\
94 \\
95 \\
114 \\
115 \\
104 \\
123 \\
104 \\
102 \\
87\end{array}$ & $\begin{array}{l}52 \\
48 \\
50 \\
53 \\
62 \\
60 \\
24 \\
59 \\
71 \\
55\end{array}$ & $\begin{array}{r}88 \\
100 \\
108 \\
121 \\
113 \\
112 \\
97 \\
105 \\
94 \\
95\end{array}$ & $\begin{array}{l}50 \\
47 \\
45 \\
65 \\
59 \\
61 \\
43 \\
57 \\
66 \\
69\end{array}$ & $\begin{array}{r}110.00 \\
121.00 \\
185.00 \\
200.00 \\
287.00 \\
265.00 \\
90.00 \\
230.00 \\
\overline{135} 00\end{array}$ & $\begin{array}{r}96.00 \\
124.00 \\
155.00 \\
208.00 \\
279.00 \\
272.00 \\
104.00 \\
240.00 \\
- \\
139.00\end{array}$ \\
\hline & Mean & 101 & 57 & 104 & 57 & 19163 & 189.13 \\
\hline
\end{tabular}

The testicles of the 10 -months old "Pustybor" still retained the transverse position and the inguinal ligament was only faintly differentiated in this bison. In all the above-mentioned bison the left testicle protruded slightly in front of the right testicle. Differences in the size of the testicles between individuals in this age group are relatively small, but the weight of the testicles of $10-\mathrm{m}$.nths old "Pustybor" was almost twice as great as that of the testicles of one-month old »Plakat«. 
The data given in Table 2 show that the dimensions, and in particular the weight of the testicles of European bison in the other age groups, are characterized by considerable individual variation. The dimensions and weight of the testicles of Puck «, »Posusz « and "Pomruk « were not taken into consideration when calculating mean values as the first exhibited bilateral and the others right-sided cryptorchismus.

Tunica albuginea testiculorum in adult European bison, together with the epiorchium, has a mean thickness of $1.24 \mathrm{~mm}(\max 1.46$, min 1.05, $\mathrm{mm}$ ). It is closely knit and from it numerous trabeculae of connective tissue pass into the interior of the gland. No distinct interlobular septa can be seen macroscopically.

Mediastinum testis in the form of an axial strand of connective tissue from 1 to $4 \mathrm{~mm}$ wide, extends along the long axis for $3 / 4$ of its length, starting from extremitas capitata. It is situated almost centrally with, a tendency to approach the epididymal surface (Photo $2-\mathrm{B}, \mathrm{C}$ and 3 ).

Ductuli efferentes running from the mediastinum testis, surrounded by abundant connective tissue, leave the testicle near the upper pole. They penetrate into the head of epididymis on the convex testicular surface of the proximal arm of the head of epididymis, near its dorsocaudal margin.

\section{EPIDIDYMIS, DUCTUS DEFERENS, SPERMATIC CORD}

The epididymis (Fig. 2) begins with a strongly thickened head ( $\mathrm{A}-\mathrm{g}$; $\mathrm{B}$ and $\mathrm{C}-\mathrm{e}, \mathrm{f}, \mathrm{g}$ ) adhering to the upper pole of the testicle. The head passed into the body $(A-j)$ situated caudolaterally and then to the tail of the epididymis ( $A$ and $B-k$ ) situated caudoventrally in relation to the lower pole of the testicle.

The head of the epididymis is similar in shape to a triangle with its base directed to the base of the spermatic cord $(\mathrm{C}-\mathrm{i})$, and the apex reaching almost to the outline of the anterio-medial surface of the testicle $(B-e, C-e)$. The head is formed of two roots, the proximal and distal 1 ). The proximal root (f) is connected in the way previously described with the testicle. The breadth of this root in adult individuals is greater than the breadth of the distal root $(\mathrm{g})$. In the material examin$e d$ this dimension exceeds $50 \%$ of the breadth of the base of the epididymis head $(h)$. The distal root passed from the apex of the epididymis head at an acute angle to the side and back. Its breadth forms about $40 \%$ of the breadth of the base. The body of the epididymis, slightly

1) Terms introduced by O. R. Sch 1 u mperger (1954). 
widened in the initial part, retains almost identical dimensions throughout its length (Table 3 ).

The tail of the epididymis, also formed of two roots closely adhering to each other, is attached to the testicle caudolaterally from its lower pole. The clavate apex of the cauda epididymidis is directed backwards and slightly downwards. The proximal root (which is a continuation of the body) has a smaller lumen than the distal root (Photo 3). Ligamentum testis proprium is strong, and short.

In the individuals examined there were no connections between the free margin of the epididymis and the epididymal surface of the testicle. As a result bursa testiculorum is capacious and is uninterruptedly connected with cavum scroti.

Table 3.

Measurements of epididymis in $\mathrm{mm}$.

\begin{tabular}{|c|c|c|c|c|c|c|c|}
\hline \multirow{2}{*}{ No. } & \multirow{2}{*}{ Name } & \multicolumn{2}{|c|}{$\begin{array}{c}\text { Breadth of head of } \\
\text { epididymis }\end{array}$} & \multirow{2}{*}{ Base } & \multicolumn{3}{|c|}{ Breadth of corpus } \\
\hline & & $\begin{array}{c}\text { Proximal } \\
\text { root }\end{array}$ & $\begin{array}{c}\text { Distal } \\
\text { root }\end{array}$ & & Initial & Midway & Terminal \\
\hline $\begin{array}{l}1 \\
2 \\
3 \\
4 \\
5 \\
6 \\
7 \\
8\end{array}$ & $\begin{array}{l}\text { Putnar } \\
\text { Pug II } \\
\text { Pozew } \\
\text { Pustelnik } \\
\text { Polamaniec } \\
\text { Pokorny } \\
\text { Pluszez } \\
\text { Plato }\end{array}$ & $\begin{array}{l}18 \\
26 \\
17 \\
17 \\
35 \\
35 \\
28 \\
55\end{array}$ & $\begin{array}{l}14 \\
20 \\
12 \\
16 \\
22 \\
21 \\
21 \\
21\end{array}$ & $\begin{array}{l}34 \\
47 \\
28 \\
37 \\
57 \\
58 \\
49 \\
56\end{array}$ & $\begin{array}{r}9 \\
15 \\
9 \\
15 \\
17 \\
18 \\
12 \\
11\end{array}$ & $\begin{array}{r}8 \\
9 \\
9 \\
12 \\
16 \\
16 \\
10 \\
9\end{array}$ & $\begin{array}{r}10 \\
8 \\
10 \\
17 \\
17 \\
16 \\
8 \\
10\end{array}$ \\
\hline
\end{tabular}

Ductus deferens running from the tail of the epididymis and attached to mesodeferens lies flat along the caudomedial surface of the testicle. Parallel to the ductus deferens and craniad from it a distinctly thickened band can be seen situated along the anterior margin of the plica ductus deferentis and covered by this fold. It accompanies the ductus de$f$ erens in the region of the spermatic cord and inguinal canal (cf. p. 518). Beginning from the epididymidal tail, the ductus deferens forms a series of turns up to the level of the distal $3 / 4$ of the long axis of the testicle, then runs straight forward and enters into the composition of the spermatic cord.

The spermatic cord near the external inguinal ring is oval in shape in the cross-section, and round at the level of collum scroti (Photo 2-A). $M$. cremaster externus, in the region of the inguinal canal, lies on the lateral side of the spermatic cord. After leaving the canal the muscle mentioned above is at first situated caudad, then at the level of the 
collum scroti caudolaterally from the spermatic cord (Photo 2-A-a). In this part $m$. cremaster externus surrounds the spermatic cord over an area of $1 / 2$ to $1 / 3$ of its circumference. Ventrad this muscle on the posterior side attains the level of the head of the epididymis. On the lateral side it produces several flat fascicles ensheathing processus vaginalis below the head of epididymis also. Among the European bison dissected, in two individuals these fascicles extend to the level of cauda epididymidis. In the region of the spermatic cord the ductus deferens, together with the accompanying band (the residuum of the corresponding embryonic Millerian duct), jointly attached to a relatively long mesodeferens are located behind the vascular part of the spermatic cord. Photo 2-A illustrates the reciprocal relation of these elements in the left and right spermatic cord at the level of the epididymidal head.

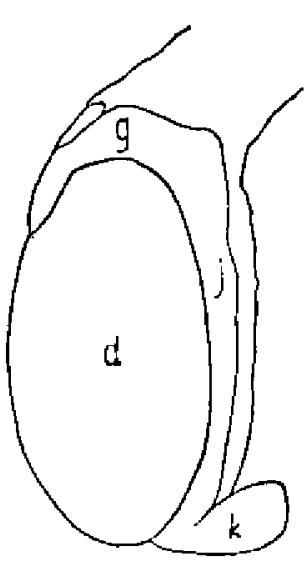

A

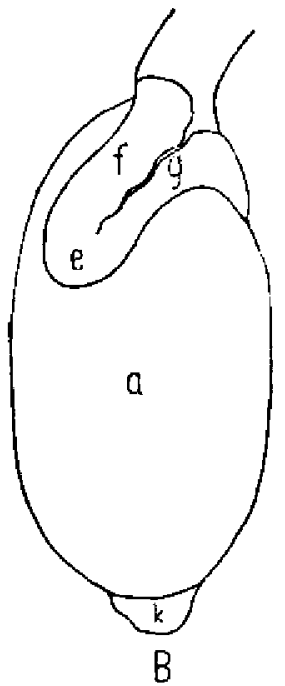

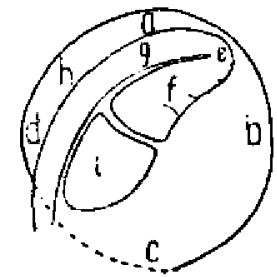

C

Fig. 2. Plan of situation of epididymis in relation to testicle (left testicle). $a, b, c, d$ - surfaces: cranial, medial, caudal and lateral of the testicle; e - apex; $f$ - proximal root: $g$ - distal root of head of epididymis; $h$ - breadth of base of epididymal head; $i$ - position of vascular part of the spermatic cord; $j$ - corpus; $k-$ tail of epididymis.

Between the left and right spermatic cords, above the penis, a mass of fat and connective tissue accumulates in the European bison. In this region there are also the inguinal superficial lymphonodes, two of which occurred on each side. Cranially they are situated in front of the spermatic cords above the penis. Caudally behind the spermatic cords, below the sigmoid flexure of the penis.

Ductus deferens, after leaving the internal inguinal ring runs, attached by the deferential fold, along the internal surface of the abdominal wail. 
After a longer or shorter distance (depending on the degree of development of uterus masculinus) the differential fold joins with the fold of the other side to form plica urogenitalis. The »band " accompanying the ductus deferens, after reaching the apex of the uterine horn of the uterus masculinus, penetrates into its wall (cf. Fig. 3 and Photo 5). The ductus deferens, on the other hand, passes in the direction of the lateral margin of the horn and is situated ventrally along this margin. In some European bison the wall of the uterine horn surrounded, the ductus deferens in such a way that it was necessary to cut open the uterine wall in order to trace its course. At the level of the undivided portion of the uterus masculinus the ductus deferentes leave the latter and run in the urogenital fold towards the urethra. The end parts of ductus deferentes are markedly thickened and exhibit structure typical of ampulla ductus deferentis.

In the group of individuals up to ten months old differences in the length of ductus deferentes are very slight.

In European bison over two years old the length of ductus deferentes (Fig. $1 \mathrm{E}: 1-3$ ) varied with the individual irrespective of age and size of the animal (cf. Tables 1 and 4).

Ductus deferentes end jointly with the excretory ducts of the vesicular glands on the colliculus seminalis in openings similar in appearance to slits (Photo 14).

V. THE SCROTUM AND THE COVERING STRUCTURES OF THE TESTICLES, OF THE EPIDIDYMIS AND OF THE SPERMATIC CORDS

The scrotum in the European bison is situated in the inguinal region on the level of the proximal curve of the sigmoid flexure of the penis. In the fixed specimens it is laterally flattened with shallow faintly marked longitudinal grooves (Photo 1). Collum scroti is only faintly differentiated and its cross-section below the penis is approximately oval, with its long axis situated obliquely to the frontal plane.

The left spermatic cord is situated craniad, and the right caudad from this plane. The testicles are similarly situated in the scrotal sac, the left advanced in front of the right by approximately half the transverse dimension. In the fixed cadavers this forwards shift is even more marked (Photo 2, B and C).

At a distance of 10 to $15 \mathrm{~cm}$ to the front the collum scroti and to the side from a median line there are rudimentary teats-papilae uberis, two a side (Photo 1-c).

The skin of the scrotum is coverd with shorter and scantier hair than the hair of the adjacent regions. Thickness of the skin on the level of 
collum scroti is from 11 to $16 \mathrm{~mm}$ in adult European bison. Halfway along the length of the scrotum this measurement varies from 4 to 6 $\mathrm{mm}$, and at the apex of the scrotum from 1 do $2.5 \mathrm{~mm}$.

Tunica dartos is thickest in the region of the collum scroti, and in the area of septum scroti, where the thickness of the dartos is as much as 4-5 mm. Stratum subdartoicum is fairly dense in texture. The presence in this layer of loose connective tissue is most distinct on the apex of the scrotum. Fascia superficialis scroti adheres closely to this stratun: (particularly on the side of septum scroti), and can easily be separatec

Table 4.

Length of ductus deferentes in millimetres according to age groups.

\begin{tabular}{|c|c|c|c|c|c|}
\hline \multirow{2}{*}{ No. } & \multirow{2}{*}{ Name } & \multicolumn{2}{|c|}{$\begin{array}{l}\text { Total length of } \\
\text { ductus deferentes }\end{array}$} & \multicolumn{2}{|c|}{$\begin{array}{c}\text { Including length of } \\
\text { ampullae }\end{array}$} \\
\hline & & Right & Left & Right & Left \\
\hline 1 & Pos & 202 & 225 & 23 & 26 \\
\hline 2 & Pub & 272 & 280 & 20 & 21 \\
\hline 3 & Pom & 265 & 230 & 20 & 25 \\
\hline \multirow[t]{2}{*}{4} & Plakat & 275 & 292 & 35 & 33 \\
\hline & Mean & 254 & 257 & 25 & 25 \\
\hline \multirow{3}{*}{$\begin{array}{l}5 \\
6\end{array}$} & Poronin & 840 & 743 & 66 & 62 \\
\hline & Putnar & 610 & 600 & $\varepsilon 9$ & 115 \\
\hline & Mean & 725 & 672 & 77 & 89 \\
\hline 7 & Pug II & 703 & 710 & 148 & 120 \\
\hline 8 & Pozew & - & - & 121 & 100 \\
\hline 9 & Puer & 570 & 720 & 112 & 115 \\
\hline 10 & Polamaniec & 740 & 690 & 115 & 112 \\
\hline \multirow[t]{2}{*}{11} & Pokorny & 795 & 630 & 115 & 119 \\
\hline & Mean & 708 & 688 & 125 & 116 \\
\hline 12 & Posusz & 505 & 712 & 87 & 96 \\
\hline $1 \overline{3}$ & Pluszez & 712 & 745 & 90 & 82 \\
\hline 14 & Plamiec & 792 & 709 & 92 & 82 \\
\hline \multirow[t]{2}{*}{$\begin{array}{l}17 \\
15\end{array}$} & Pomruk & 631 & 736 & 86 & 101 \\
\hline & Mean & 712 & 726 & 89 & 80 \\
\hline
\end{tabular}

from fascia profunda scroti. Profuse, mainly fat, connective tissue, thrusts between the two fascial layers at the level of collum scroti and forms a continuation of the accumulation previously described of connective tissue separating the spermatic cords.

Fascia cremasterica can easily be separated from fascia transversa. The latter, on the other hand, separates from the serous membrane ony 
at the level of the spermatic cord. In the remainder of the area fascia transversa adheres to the surface of processus vaginalis, forming lamina fibrosa of the parietal layer of the vaginal process - periorchium s. tunica vaginalis communis. The visceral layer of the vaginal process epiorchium s. tunica vaginalis propria behaves typically in the European bison, that is, it closely covers tunica albuginea of the testicle and participates in the formation of mesoepididymis.

\section{THE GENITAL ACCESSORY GLANDS}

1. The ampullae ductuum deferentium

The structure of ampulla ductus deferentis in the European bison examined suggests that the thickening of this part of the ductus deferens is due both to increase in the thickness of the wall and to increase in the diameter. The diameter of the duct is formed by several niche-shaped branchings. Krölling (1930) found numerous glandular elements in the mucous membrane of the ampullae ductuum deferentium in the European bison, which points to the glandular character of the ampulla.

In the material examined four groups, corresponding to the age groups, can be distinguished in respect of length of ampulla ductus deferentis (cf. Table 4). While the considerable difference in this dimension between calves up to one month old and older individuals is of course obvious, the differences among the remaining animals are remarkable. This dimension decreases in animals over 10 years old. As the length of ductus deferentes varies considerably in all the groups, irrespective of the body measurements, calculation was made of the length of ampullae ductus deferentes in the form of per cent of length of the corresponding ductuum deferentium varies considerably in all the groups, irrespective of the body measurements, calculation was made of the length of ampullae ductuum deferentium in the form of per cent of length of the corresponding ductus deferens (Table 5). These data show that the participation of ampulla ductus deferentis in the length of the ductus deferens increases with age, attaining a maximum at $6-10$ years of age. In older bison the values of this ratio again decrease, approaching the corresponding values in animals from $2-3$ years old. This may be connected with the process of senescence, although data obtained from pedigree books do not indicate that the reproductive capacity of male bison markedly decreased at ages over ten years ("Plamiec $789 \star$, "Plish 229 , „Pluvius II 546 «, "Podbipięta 738 «). 


\section{Vesiculae seminates}

Two vesicular glands occur in the European bison (Photo 5, 6, 7). They are formed by elongated glandular packets, surrounded by a layer from 1.5-2.5 $\mathrm{mm}$ thick of connective tissue with abundant vessels, nerve fibres and smooth muscle fibres. Situated laterally from ampullae ductuum deferentium these glands are hidden, together with the ampullae

Table 5 .

Ratio of length of ampulla ductus deferentis to length of ductus deferens in percentages (according to age groups).

\begin{tabular}{|r|r|r|r|}
\hline \multirow{2}{*}{ No. } & Name & \multicolumn{2}{|c|}{ Ampulla ductus deferentis } \\
\cline { 2 - 4 } & & Right o & Left of \\
\hline 1 & Pos & 11.40 & 11.60 \\
3 & Pub & 7.35 & 7.60 \\
4 & Pom & 7.55 & 9.13 \\
& Plakat & 12.73 & 11.30 \\
\hline & Mean & 975 & 8.34 \\
\hline 5 & Poronin & 7.85 & 8.34 \\
6 & Putnar & 14.59 & 19.16 \\
\hline & Mean & 11.22 & 13.75 \\
\hline 7 & Pug II & 21.05 & 16.90 \\
8 & Puer & 19.64 & 15.97 \\
9 & Polamaniec & 15.54 & 16.23 \\
10 & Pokorny & 14.47 & 18.88 \\
\hline & Mean & 17.67 & 16.99 \\
\hline 11 & Posusz & - & 13.48 \\
12 & Pluszcz & 12.64 & 11.00 \\
13 & Plamiec & 11.71 & 11.56 \\
14 & Pomruk & 13.63 & 13.72 \\
\hline & Mean & 12.66 & 12.44 \\
\hline
\end{tabular}

and uterus masculinus, in the urogenital fold. They are covered over the cranial $3 / 4$ of their length by this fold. The external surface of the glands is folded, which is connected with their lobular structure and gives the whole a racemose appearance (Photo 6). On the posterior end of eack of the glands there is a lobe, situated medially, which is connected with a similar lobe of the gland on the opposite side by connective tissue. There is a sort of transverse isthmus thrusting between the ampullae ductuum deferentium and the urethra (Photo $7 \mathrm{~b}$ ). This commissure, of 
a connective tissue character, is united with the end parts of the ductus deferentes and urethra by the surrounding connective tissue. The main deferent duct runs from each of these glands and ends on the ventral wall of the ductus deferens.

The measurements made on the material at our disposal show that the dimensions of the vesicular glands increase markedly up to the age of about 4 years (Table 6). The predominance of dimensions of one gland

Table 6.

Measurements of vesiculae seminales according to age groups.

\begin{tabular}{|c|c|c|c|c|c|}
\hline \multirow[b]{2}{*}{ No. } & \multirow[b]{2}{*}{ Name } & \multicolumn{2}{|c|}{ Right vesicle } & \multicolumn{2}{|c|}{ Left vesicle } \\
\hline & & $\begin{array}{l}\text { Longitudinal } \\
\text { messurement }\end{array}$ & $\begin{array}{l}\text { Transverse } \\
\text { measurement }\end{array}$ & $\begin{array}{l}\text { Longitudinal } \\
\text { measurement }\end{array}$ & $\begin{array}{l}\text { Transverse } \\
\text { measurement }\end{array}$ \\
\hline $\begin{array}{l}1 \\
2 \\
3 \\
4\end{array}$ & $\begin{array}{l}\text { Pos } \\
\text { Pub } \\
\text { Pom } \\
\text { Plakat }\end{array}$ & $\begin{array}{l}23 \\
22 \\
30 \\
35\end{array}$ & $\begin{array}{r}7 \\
5 \\
6\end{array}$ & $\begin{array}{l}26 \\
31 \\
28 \\
33\end{array}$ & $\begin{array}{l}9 \\
7 \\
8\end{array}$ \\
\hline & Mean & 28 & 6 & 39 & 8 \\
\hline $\begin{array}{l}5 \\
6 \\
7\end{array}$ & $\begin{array}{l}\text { Poronin } \\
\text { Putnar } \\
\text { Puck }\end{array}$ & $\begin{array}{l}54 \\
86 \\
83\end{array}$ & $\begin{array}{l}17 \\
32 \\
28\end{array}$ & $\begin{array}{l}52 \\
90 \\
63\end{array}$ & $\begin{array}{l}15 \\
17 \\
21\end{array}$ \\
\hline & Mean & 74 & 26 & 68 & 18 \\
\hline $\begin{array}{r}8 \\
9 \\
10 \\
11 \\
12 \\
13 \\
14 \\
15 \\
16 \\
17\end{array}$ & $\begin{array}{l}\text { Puzor } \\
\text { Pug II } \\
\text { Pozew } \\
\text { Puer } \\
\text { Polamaniec } \\
\text { Pokorny } \\
\text { Posusz } \\
\text { Pluszez } \\
\text { Plamiec } \\
\text { Pomruk }\end{array}$ & $\begin{array}{r}100 \\
120 \\
83 \\
90 \\
112 \\
112 \\
95 \\
91 \\
92 \\
111\end{array}$ & $\begin{array}{l}28 \\
30 \\
19 \\
35 \\
41 \\
44 \\
51 \\
31 \\
39 \\
36\end{array}$ & $\begin{array}{r}95 \\
102 \\
78 \\
110 \\
110 \\
108 \\
101 \\
85 \\
98 \\
119\end{array}$ & $\begin{array}{l}30 \\
35 \\
25 \\
38 \\
35 \\
\mathbf{3 5} \\
\mathbf{3 7} \\
38 \\
18 \\
\mathbf{4 1}\end{array}$ \\
\hline & Mean & 101 & 35 & 101 & 33 \\
\hline
\end{tabular}

over the other varies with the individual. In European bison over five years old there is no relation between the size of the glands and the body dimensions (cf. »Pug II«, »Pozew", "Plamieck).

\section{The prostate}

The prostate - consists of corpus prostatae and pars disseminata. The body of the prostate is situated on the dorsal surface of the urethra in the immediate vicinity of the ostiums of ductus deferentes and the excretory ducts of the vesicular glands (Photo 6). 
In the material examined the body of the prostate (Photo 6, d) was formed of two lobes in calves up to one month old. In one-day old "Pos $"$ and $" P u b *$, and in seven-day old "Pom*, the lobes of the body of the prostate have remained completely independent. In shape and size they are similar to flax seeds arranged obliquely in relation to each other. In one-month old "Plakat" the two lobes are closer to each other but can be separated without difficulty. In bison over two years old the body of the prostate takes the form of a single cylindrical formation. The more or less distinct clavate ends are the "vestige of the bilobular structure of the gland. The two Iobes adhere closely to each other and in adult individuals the border between them cannot be determined macroscopically. The transverse dimension of the body of the prostate (Fig. 1, C, 5--6) in adult European bison varies from $23-54 \mathrm{~mm}$ (mean $33 \mathrm{~mm}$ ). The longitudinal measurement of the right lobe is from 5-$8 \mathrm{~mm}$ (mean $6 \mathrm{~mm}$ ) and the left lobe from 5 to $9 \mathrm{~mm}$ (mean $7 \mathrm{~mm}$, $\mathrm{n}-6)$. Development of the lobes in different individuals does not exhibit any important differences. It was only in the bison "Polamaniec " that the right lobe was far less developed than the left.

Pars disseminata prostatae begins at a distance of about $0.5 \mathrm{~cm}$ caudad from colliculus seminalis.

At first the amount of glandular tissue is small and is situated on the dorsal and dorso-lateral side of the urethra (Photo 16-3). The further caudad, the more the measurements of the glandular lobes increase, so that halfway along pars pelvina urethrae masculinae, pars disseminata prostatae surrounds the urethra completely from the top and sides, leaving only a narrow band free on the ventral side (Photo 16-5, 6). In this part the glandular layer on the dorsal side can be as much as $15 \mathrm{~mm}$ thick, and on the lateral sides from 8 to $10 \mathrm{~mm}$. In the area of the posterior half of the pelvic portion of the urethra the glandular parenchyma also thrusts under the urethra on the ventral side (Photo $16-8,9,10$ ), gradually becoming thinner. The scuff « formed in this way with the pars disseminata prostatae ends in a conical shape at a distance of about $2 \mathrm{~cm}$ from the transition of pars pelvina urethrae into pars bulbi urethrae.

The openings of the deferent ducts of the prostate are arranged in four rows on the dorsal wall of the urethra (Photo 14).

\section{The bulbourethral glands}

The bulbourethral glands - glandulae bulbourethrales -- are formed of the lobes connected by profuse connective tissue. As a result a flat heart-shaped formation is created, the double structure of which is ma- 
nifested by the convex anterior upper margin and the shallow groove on the posterior surface. The defferent ducts of the glands join in one common duct from 1.2 to $2 \mathrm{~cm}$ long which runs along the caudo-dorsal surface of the urethra. The duct opens into a recess situated on the caudo-dorsal wall of pars bulbi urethrae. The recess is bounded by a fold of mucous membrane in the form of an inverted letter $V$.

This organ, with the structure described above, is situated on the boundary line between the pelvic and bulbar portion of the urethra (Photo 15).

In adult bison the longitudinal dimension of the gland (Fig. 1, D, 1-3) was from 17 to $28 \mathrm{~mm}$ (mean $21 \mathrm{~mm}$ ). The transverse measurement (Fig. 1, D, 1-2) varies from $15-33 \mathrm{~mm}$ (mean $27 \mathrm{~mm}$ ).

Several muscles surround the glands from all sides. The caudoventral part is covered by the pars bulbi and together with it, by $m$. bulbocavernosus.

The caudodorsal surface covers an individually varying (in respect of occurrence and direction in which the fibres run) muscle, the structure and insertions of which correspond to $\mathrm{m}$. ischiobulbosus described in the ram by $\mathrm{Br}$ a u ell (1868). Muscles such as m. ischiourethralis, $m$. urethroglandularis and partly $m$. bulboglandularis thrust between the anterioventral surface of the gland described and the urethra. Of these muscles, only the first occurred in all the dissected animals and was characterized by a continuous course (Photo 6). The pelvic insertion of this muscle is situated on the internal surface of the tuber ischii and is surrounded by the strong $m$. ischiocavernosus. The thin slender belly of the muscle runs medially towards the urethra and passes into an aponeurosis, which thrusts under gl. bulbourethralis, surrounds the urethra and unites with the same muscles of the opposite side. Between the connective tissue surrounding the gland and the aponeurosis there is a macroscopically visible exchange of fibres. The adurethral surface of the bulbourethral gland, where not separated by muscles, adheres closely to the pelvic part of the urethra. In this place $m$, urethralis is thin and the bulbourethral gland is separated from the apex of pars disseminata prostatae by the aponeurosis of the urethral muscle only.

\section{TIE UTERUS MASCULINUS}

Among the seventeen male European bison which we examined in this respect the uterus masculinus occurred in sixteen cases. This organ exhibited a varying degree of development in different individuals and several types were distiguished on this basis (Fig. 3). 
In the case of nine bison the external appearance is deceptively similar in appearance to the uterus in the female. Paired horns and undivided part could be distinguished in it.

The horns, like the uterine horns of the cow, were directed with greater curvature upwards and forwards, and lesser curvature downwards and backwards. The turn of the horns was not however complete, and the apices of the horns extended into "bands" accompanying the ductus deferentes. The undivided part, at first wide, becomes narrower, then widens out again in the terminal part (Photo $5,6,7$ ). The whole organ was dorso-ventrally flattened, this being most marked in the

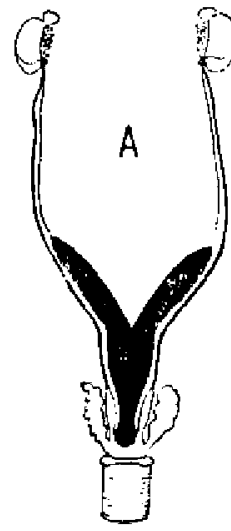

9

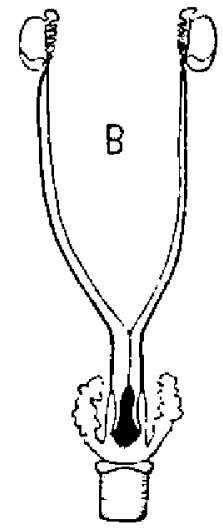

4

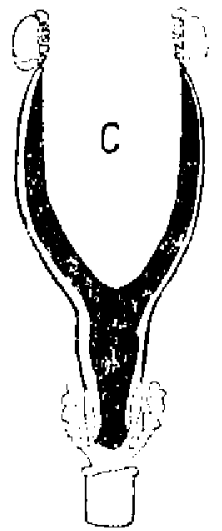

2

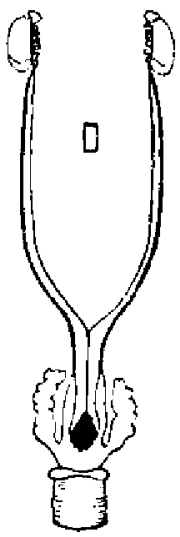

1

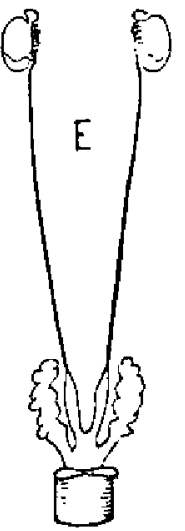

1

Fig. 3. Plan of types of uterus masculinus in the European bison. Numbers under figures represent the number of cases found.

terminal part, where thickness never exceeded $10 \mathrm{~mm}$. Plica urogenitalis covers uterus masculinus together with the final parts of ductus deferentes and the vesicular glands, behaving in the region of the pelvic cavity in a similar way to that found in females. In adult European bison with this type of uterus the dimensions (Fig. 1, C) of its different parts were as follows:

(a) length of right horn: (1-2) 115 to $260 \mathrm{~mm}$, mean $185 \mathrm{~mm}$

(b) length of left horn: (2-3) 100 to $270 \mathrm{~mm}$, mean $160 \mathrm{~mm}$

(c) length of undivided part: (2-4) 185 to $208 \mathrm{~mm}$, mean $198 \mathrm{~mm}$

In four bison uterus masculinus occurred in the form of an undivided conical duct passing to the front in a single "band «. On the border of plica urogenitalis the sband s divided into two, which behaved similarly in their continued course to that in the first type. Among the three bison possessing this type of uterus there were individuals in which 
growth was not complete and it is thus difficult to speak of mean dimensions of this organ in this group.

A similarly undivided uterus masculinus was found in the European bison "Polamaniec*. It was ampullary in shape, in the form of an oval vesicle measuring $15 \mathrm{~mm} \times 20 \mathrm{~mm}$. We therefore differentiated this uterus into a separate type (D) on these grounds.

Although in two further European bison uterus masculinus was similar in structure to that in the first type, it differed considerably in dimensions (cf. in Table $7-$ Puck «, "Pug II ). The uterine horns of these uteri extended to the internal inguinal rings, and in "Pug II even penetrated into the area of the inguinal canal.

Table 7.

External measurements of uterus masculinus in millimetres.

\begin{tabular}{|c|c|c|c|c|c|}
\hline \multirow{2}{*}{ No. } & \multirow{2}{*}{ Name } & \multirow{2}{*}{$\begin{array}{c}\text { Type of } \\
\text { uterus } \\
\text { acc. to } \\
\text { Fig. } 3\end{array}$} & \multicolumn{2}{|c|}{ Length of horns } & \multirow{2}{*}{$\mid \begin{array}{c}\text { Length of } \\
\text { undi- } \\
\text { vided } \\
\text { part }\end{array}$} \\
\hline & & & Right & Left & \\
\hline 1 & Pos & A & 39 & 40 & 68 \\
\hline 2 & Pub & B & - & - & 50 \\
\hline 3 & Pom & B & - & - & 30 \\
\hline 4 & Plakat & A & 30 & 35 & 80 \\
\hline о̃ & Poronin & $B$ & - & - & 40 \\
\hline 6 & Putnar & A & 120 & 135 & 180 \\
\hline 7 & Puck & C & 290 & 320 & 135 \\
\hline B & Puzor & A & 180 & 120 & 200 \\
\hline 9 & Pug II & C & 460 & 510 & 275 \\
\hline 10 & Pozew & (E) & - & & - \\
\hline 11 & Puer & A & 115 & 160 & 200 \\
\hline 12 & Polamaniec & $\mathrm{D}$ & - & - & 19 \\
\hline 13 & Pokorny & A & 240 & 270 & 202 \\
\hline 14 & Posusz & B & - & - & 20 \\
\hline 15 & Pluszcz & A & 260 & 100 & 185 \\
\hline 16 & Plamiec & A & 151 & 132 & 208 \\
\hline 17 & Pomruk & A & 162 & 180 & 193 \\
\hline
\end{tabular}

Uterus masculinus in all the dissected European bison, irrespective of type, had a lumen, which only in "Plakat w was interrupted in the undivided part by adhesion of the walls over a length of about $5 \mathrm{~mm}$. The lumen of the uterus was connected with the lumen of the urogenital duct by means of the opening located on colliculum seminalis (Photo 14).

The walls of uterus masculinus of the first and third types exhibited different parts in respect of structure and colour of the mucous membrane.

The horns were covered by dark coloured mucous membrane not exhibiting folding. In some individuals small prominences were evident 
in the shape of longitudinal folds, and in three they appeared as bead-like thickenings. The thickness of the walls of the horns, like the thickness of the walls of the other parts of uterus masculinus, differed in different individuals, varying from 1 to $1.37 \mathrm{~mm}$. The wbands " running from the horns (mentioned previously in discussing the course of the ductus deferentes) had a lumen in the aduterine parts and were covered with simple columnar epithelium. The extent of the lumen in a direction towards the testicles could be determined macroscopically over sections of different length.

The horns passed into the region of the undivided part of uterus masculinus, which is widest and situated furthest craniad (Photo 6 and 7). It is covered by mucous membrane devoid of macroscopically visible folds and similar in colour to the mucous membrane of the horns. Among the eleven European bison (types $\mathrm{A}+\mathrm{C}$ ) in seven a length-ways septum, dividing the lumen into two halves, occurred on the wall of the last-mentioned section. This septum is the starting point of the division into horns. The border of the septum was formed by muscle tissue covered by mucous membrane (4 cases), or was only the doubling of the mucous membrane ( 3 cases). The thickness of the walls of this part of the organ varied from $1.2 \mathrm{~mm}$ to $2.9 \mathrm{~mm}$.

The next section of the length from 20 to $60 \mathrm{~mm}$ was covered by light-coloured mucous membrane forming circular folds visible under a magnifying glass with $3 \times$ magnification. The walls in this section thicken distinetly, reaching as much as 2.30 to $4.36 \mathrm{~mm}$.

The next section, strongly narrowed in the majority of the European bison (Photo $7 \mathrm{~d}$ ) and from 80 to $120 \mathrm{~mm}$ long, was covered by mucous membrane slightly darker in colour than the preceding, with a slight yellowish or brown shade. It was covered by longitudinal low folds perpendicular to the folds previously described. The thickness of the walls in the section varied from 0.5 to $2.30 \mathrm{~mm}$.

The mucous membrane in the final re-enlarged section was dark in colour. It was covered with densely arranged folds forming a sort of extension to the back of the folds of the neighbouring section. The length of this area was 5 to $17 \mathrm{~mm}$.

Histological slides made from the regions exhibiting macroscopic differences usually confirm the existence of these differences.

The wall of the horns (Photo 8,9) is lined with mucous membrane covered by simple columnar epithelium. The true layer of mucous membrane contains numerous branched tubular glands and blood vessels. Columnar epithelium lines the glands, which reach to the muscle layer. The vascular layer is clearly defined. Similar relations are exhibited by the first two sections of the undivided part, the thickness of 
the muscle layer increasing caudad, and the number of glands decreasing.

The slides from the narrowed caudal section of the undivided part exhibit a different structure (Photo 10, 11). Although the mucous membrane is also covered by simple columnar epithelium it is lower than in the previous sections. The true layer of mucous membrane does not contain glands and exhibite a large number of connective tissue fibres.

The short broadened final section, with strongly folded mucous membrane, has simple columnar epithelium (Photo 12,13). The true layer forms high tubercles under which there is a dense network of venous vessels. Scattered glands appear again. Stratum musculare is strongly developed.

\section{THE PELVIC PORTION OF THE UROGENITAL DUCT}

Colliculus seminalis is situated on the dorsal wall of the inital section of the pelvic portion of the urogenital canal (Photo 14). According to Pilar ski (1967) in the European bison colliculus seminalis is situated on the boundary between pars uralis and pars prostatica of the urethra. It forms a oval prominence, the length of which attains as much as $2 \mathrm{~cm}$ in adult bison. The posterior highest part of the colliculus which is a thickening passing into a length-ways fold running along the dorsal wall of the urogenital canal (Photo 14,d). The surface of the colliculus seminalis is depressed like a crater. The depression is surrounded by a ridge-like prominence from which the openings of the ejaculatory ducts are situated medially. On the flattened posterior surface of the colliculus in those individuals in which the lumen of uterus masculinus joins the lumen of he urogenital canal there is an opening into uterus masculinus (Photo 14).

The pelvic portion of the urogenital canal is surrounded by corpus cavernosum urethrae, beginning at the height of colliculus seminalis. At first it is situated ventrally in relation to the urethra in the form of a narrow band of erectile tissue (Photo $16-1,2$ ). At a distance of approximately $1 \mathrm{~cm}$ behind colliculis seminalis the erectile tissue surrounds the urethra on all sides (Photo 16-3). As pars disseminata prostatae develops the erectile tissue of the urethra decreases in size, retaining the thickest layer again on the ventral side of the urethra (Photo $16-4,5$ ).

The erectile tissue thickens and again surrounds the urethra in the region of the posterior half of the pelvic portion of the urogenital canal. The lumen of the cavernous sinuses markedly increases, which in the cross-section gives the appearance typical of erectile tissue (Photo $16-9,10,11)$. 


\section{TIIE PENIS}

In the penis of the male European bison, as in other mammals, it is possible to distinguish corpus penis and pars penis s. pars externa urethrae surrounded by the corpus cavernosus urethrae ${ }^{2}$ ).

\section{Corpus penis}

The corpus penis begins at the ischial arch by means of paired crura penis, which next unite to form the unpaired radix penis attached by strong short ligaments to the posterior part of symphysis ischit. In turn, radix penis extends craniad into truncus corporis penis, ending in apex corporis penis. Truncus corporis penis for $1 / 3$ of its length towards the pelvis forms the ssigmoid flexure w which is less distinct than in the domestic bull. The flexure did not occur in calves up to 7 days old in the material we dissected.

Corpus cavernosum corporis penis in the region of the two crura is surrounded by tunica albuginea. This is reinforced by fasciae of circular fibres at first loosely knit, but which, as the distance to radix penis decreases, become increasingly dense (Photo 17-1, 2). The distance between crura decreases even more not only on account of the increase in the amount of connective tissue in the walls of crura but chiefly owing to their oblique course.

When the medial walls of the two crura meet a septum is formed between the erectile tissue (Photo $22-3,4$ ) which loses its character of septum near radix penis, and as a result we have an apparently single corpus cavernosum penis in the region of radix penis (Photo $17-5,6,7)$. At the same time the contents of the vascular components of the corpus cavernosum decrease considerably in favour of the fibrous trabeculae. In the cross-section the trabeculae run in fan shape from the fibrous tissue "centrum $\%$ which exhibits a dense, compact structure. In this initial section the pentrum \& is situated immediately above the urethral groove (Photo $17-7$ ). When observing successive cross-sections of the penis, in a direction up to the apex, it can be seen that the scentrum $\%$ described above increases and is situated medially in front of the proximal curve of the sigmoid flexure. Here it has a laterally flattened shape, and the trabeculae radiate outwards from it (Photo 17 - 8). In the region of the sigmoid flexure the pcentrum " is flattened dorso-ventrally, with a tendency to division into two owing to the

\footnotetext{
2 The terminology used in describing the penis is in accordance with that used by Buchholtz (1951) and Preuss (1954) in describing the penis in domestic animals.
} 
nedial narrowing (Photo $17-10,11,12$ ). This division is even more clearly marked in the initial part of the apex (cross-section 13). In further cross-sections of the apex the scentrum an increasingly flattened lamina (Photo $17-14,15,16$ ), disappearing at a distance of about $5 \mathrm{~mm}$ from the end of the apex. In view of the fact that the descriptions given above refer to cross-sections is must be said that in the European bison a central axial band of dense fibrous tissue formed by the trabeculae of corpus cavernosum penis which crosses in this place insides spreads the erectile tissue of corpus penis. The appearance and position of the axial band differ in different sections of corpus penis and depend on the shape of the penis.

The male urethra, surrounded by corpus cavernosum urethrae, is located along the ventral surface of the body of the penis inside the urethral groove.

\section{The penile part of the urogenital duct}

The proximal end of the penile portion of the urogenital duct is surrounded by bulbus cavernosus urethrae.

Bulbus cavernosus urethrae in the European bison is at first located dorsally, then also laterally in relation to the duct. It extends between the bulbourethral glands and the place in which crura penis unite. This formed grounds for calling this section of the duct - pars bulbi urethrae ( $\mathrm{Grab}$ ow ski, 1937). After removing $m$. bulbocavernosus the bulbus in the fixed specimens is similar in shape to a steep tetrahedral pyramid with its apex turned in the direction of the penis (Photo 15). On the dorsal side of this organ there is a sharp crista highest at the end directed towards the pelvis and becoming lower ventrally. The dorso-caudal surfaces situated on the sides of this crista are slightly concave in uninjected preparations. The lateral surfaces are surrounded by a thick layer of connective tissue. Near radix penis, where the bulbus narrows, the layer of connective tissue extends to $20 \mathrm{~mm}$ on each side and fills the spaces between crura and bulbus. The bulbus built in this way is usually a single structure. It is only in the broadened end of the bulbus near the pelvis that the septum dividing corpora cavernosa bulbi into two halves can be seen in cross-sections. This septum disappears at the level of about $1 / 4$ of the proximal length of the organ.

The dimensions of bulbus vary individually in the European bison. In the material dissected the lengt of bulbus in adult bison (measured along the dorsal crista - Fig. 1 D 4-6) varied from 55 to $105 \mathrm{~mm}$. Breadth in the widest place (Fig. 1, 6, 7-5, in projection) was more stable and varied from 26 to $28 \mathrm{~mm}$. 
At first corpus cavernosum uretrae differentiates into two layers. The internal layer, with small cavernous spaces, adheres to the wall of the urethra; the externai layer, with larger spaces, is located peripherally from the former. In this initial part the urethra is situated nearer the corpus penis. The external layer of the erectile tissue, situated ventrally in relation to the urethra, is thicker (Photo $17-5,6,7$ ). Beginning with the proximal curve of the sigmoid flexure of the penis and further in the direction of the apex corpus cavernosum urethrae surrounds the urethra evenly. As a result the position of the urethra is central in corpus cavernosum in this part of the penis (Photo 17 $10,11,12$ ). In the preputial part of the penis corpus cavernosum urethrae thickens in the part situated dorsally from the urethra (Photo 17 $-15,16)$. It ceases to be macroscopically visible when the urethra passes into the urethral process.

The penile portion of the urethra and its corpus cavernosum are surrounded during its course through the urethral groove, from the back and then from the bottom, by an external layer of the tunica albuginea corporis penis. At first the part of the penis towards the pelvis up to the proximal curve of the sigmoid flexure is flattened laterally. The strongly developed ventral part of the corpus cavernosum penis protrudes above the urethral groove and can be seen througt the tunica. In the region of the flexure the penis becomes cylindrical in shape. Corpus penis completely surrounds the urethra and the external layer of tunicae albugineae thickens. The urethra together with corpus cavernosum becomes invisible from the exterior (Photo $17-10,11$, 12). On the apex of the penis the urethra is visible only in the form of a short urethral process.

The apex of the penis is covered from the exterior by the prepuce proper. Between the prepuce proper and the dorsal surface of corpus penis there is an aggregation of dense connective tissue fibres. They run obliquely from the preputial layer to apex corporis penis inserted on it at the level of sulcus galeae apicis. In the region of galea apicis penis s. galea glandis there is a thin layer of connective tissue with visible blood vessels, forming the border of galea apicis penis.

Galea apicis penis in the European bison is round in shape, with an apex dirceted backwards and to the right. There is no distinct line of demarcation between galeae penis and the posterior preputial part of the apex penis. At the level of the beginning of the urethral process on the opposite (right) side of raphe preputii there is a prominence, which in the cadavers had sharp margins and adheres flatly to the urethral process from the right side. In the organs taken from cadavers 
fixed by means of intraarterial injections the surface of this prominence is smooth and convex. The whole has the appearance of a low tubercle about $3 \mathrm{~mm}$ in diameter.

\section{Dimensions of the penis}

Table 8 gives the results of measurements of the length of the penis in European bison, measured along the ventral surface (Fig. 1, E, 8-9). It would seem that the relatively large difference in total length of the penis and length of the preputial part between the last two age groups is due to the fact that there were only two individuals in the third group.

Table 8.

Measurements of length of penis in the European bison (in $\mathrm{mm}$ ).

\begin{tabular}{|l|c|c|c|c|c|c|c|c|}
\hline \multirow{2}{*}{ Age limits } & $\begin{array}{c}\text { Number } \\
\text { of } \\
\text { cases }\end{array}$ & \multicolumn{2}{|c|}{ Total length of penis } & \multicolumn{2}{|c|}{$\begin{array}{c}\text { Length of pars preputialis } \\
\text { penis }\end{array}$} \\
\cline { 3 - 8 } & From & To & Mean & From & To & Mean \\
\hline & 3 & 206 & 252 & 231 & 34 & 36 & 35 \\
$1-7$ days & 2 & 309 & 340 & 324 & 50 & 58 & 54 \\
1-10 months & 2 & 630 & 740 & 685 & 80 & 115 & 111 \\
2-5 years & 11 & 755 & 965 & 864 & 120 & 160 & $139^{*}$ \\
over 5 years & 1 & & & & & & \\
\hline
\end{tabular}

*) - Number of cases for this mean value $=10$.

Calculation was made of the ratio between length of penis and measurements of body length of the individuals dissected (Table 9). In European bison aged from one day to ten months old these values are different and in the majority of cases exceed the corresponding value for bison over three years old. In turn in the remaining males the ratio between penis length and corresponding body measurements is constant.

\section{THE PPEPUCE}

The apex of the penis, together with galea apicis penis, is covered by the praeputium (Photo 21). The internal layer of the prepuce begins round ostium praeputiale with a narrow band of pigmented skin. The skin surrounding the ostium is covered with setaceous hairs, particularly dense and long on the dorsal side (Photo 19). It is strongly thickened and the lumen of the ostium narrow (in fixed cadavers 1 to $1.5 \mathrm{~cm}$ in diameter).

From the external surface of the abdominal wall under the thickened skin of the preputial ostium a thick flat bundle of connective tissue 
fibres radiates. It is ligamental in character and strengthens the attachment of the prepuce to the walls of the body. Inside the prepuce, from the back to the ostium, there is a region from 120 to $150 \mathrm{~mm}$ long, covered by longitudinal folds. On the dorsocranial wall in five bison there was a darkly pigmented field covered with scanty, short hairs.

Table 9.

Ratio of length of penis to external body measurements.

\begin{tabular}{|c|c|c|c|c|}
\hline \multirow{2}{*}{ No. } & \multirow{2}{*}{ Name } & \multicolumn{3}{|c|}{ Ratio to measurement } \\
\hline & & A & $\mathbf{E}$ & $\mathbf{F}$ \\
\hline $\begin{array}{l}1 \\
2 \\
3 \\
4 \\
5\end{array}$ & $\begin{array}{l}\text { Pos } \\
\text { Pub } \\
\text { Pom } \\
\text { Plakat } \\
\text { Pustybór }\end{array}$ & $\begin{array}{l}1: 5.6 \\
1: 4.5 \\
1: 4.5 \\
1: 4.3 \\
1: 5.4\end{array}$ & $\begin{array}{l}1: 2.2 \\
1: 1.8 \\
1: 1.9 \\
1: 2.2 \\
1: 3.1\end{array}$ & $\begin{array}{l}1: 2.6 \\
1: 2.5 \\
1: 3.2 \\
1: 2.9 \\
1: 3.3\end{array}$ \\
\hline & Average (age of 1 day to 7 months) & $1: 4.9$ & $1: 2.3$ & $1: 2.9$ \\
\hline $\begin{array}{l}6 \\
7\end{array}$ & $\begin{array}{l}\text { Poronin } \\
\text { Putnar }\end{array}$ & $\begin{array}{l}1: 3.4 \\
1: 3.3\end{array}$ & $\begin{array}{l}1: 1.5 \\
1: 1.7\end{array}$ & $\begin{array}{l}1: 2.2 \\
1: 2.4\end{array}$ \\
\hline & Average (age of $2-3$ yrs.) & $1: 3.4$ & $1: 1.6$ & $1: 2.3$ \\
\hline \begin{tabular}{r|}
8 \\
9 \\
10 \\
11 \\
12
\end{tabular} & $\begin{array}{l}\text { Puzor } \\
\text { Pug II } \\
\text { Pozew } \\
\text { Połamaniec } \\
\text { Pokorny }\end{array}$ & $\begin{array}{l}1: 3.2 \\
1: 2.9 \\
1: 3.3 \\
1: 3.1 \\
1: 29\end{array}$ & $\begin{array}{l}1: 1.5 \\
1: 1.4 \\
1: 1.6 \\
1: 1.5 \\
1: 1.5\end{array}$ & $\begin{array}{l}1: 2.1 \\
1: 2.1 \\
1: 2.5 \\
1: 2.3\end{array}$ \\
\hline & Average (age of $5-10 \mathrm{yrs}$ ) & $1: 3.1$ & $1: 1.5$ & $1: 2.2$ \\
\hline \begin{tabular}{l|}
13 \\
14 \\
15 \\
16
\end{tabular} & $\begin{array}{l}\text { Posusz } \\
\text { Pluszcz } \\
\text { Plamiec } \\
\text { Plato }\end{array}$ & $\begin{array}{l}1: 3.3 \\
1: 3.4 \\
1: 3.2 \\
1: 3.0\end{array}$ & $\begin{array}{l}1: 1.5 \\
1: 1.5 \\
1: 1.4\end{array}$ & $\begin{array}{l}1: 2.5 \\
1: 2.2 \\
1: 1.7\end{array}$ \\
\hline & Average (age over 10 yrs.) & $1: 3.2$ & $1: 1.5$ & 1:2.1 \\
\hline
\end{tabular}

An extension of this region caudad is a zone of circular folds from 80 to $100 \mathrm{~mm}$ long. The prepuce proper - laminc penis praeputii, ensheathes the penis forming several circular folds. Raphe praeputii runs along the ventral surface of the apex penis, towards the right side, and at the level of the base of the urethral process disappears, in the case of young individuals, in numerous longitudinal folds. In adult bison the raphe ends singly.

In European bison up to ten months old parietal and visceral laminae praeputii cohered. In seven months old "Pom" and one month old "Pla- 
kat" this adhesion was complete. In ten months old "Pustybor" the dorsal surface of galea apicis penis was already free. The ventral surface of the galea was still attached to the parietal layer of the prepuce by numerous small bands (Photo 18).

\section{THE PREPUTIAL MUSCLES AND THE EXTRENSIC PENILE MUSCLES}

Several muscles are connected topographically and functionally with the genital organs. Some of them, such as m. cremaster externus, or the group of muscles situated in the region of the bulbourethral glands, have already been mentioned in the appropriate sections of this study. $M$. urethralis was described in the study on the urinary system of the European bison (Pilarski, 1967). Among the muscles connected with the prepuce and penis of the European bison mention must be made of the preputial muscles, $m$. bulbocavernosus, $m$. ischiocavernosus and $m$. retractor penis.

$M m$. praeputiales occur in European bison in the form of paired cranial and caudal $m m$. praeputiales. They are connected with the skin musculature of the trunk.

$M m$. praeputiales craniales begin at the level of linea alba caudad from the xiphoid process. The flat bellies of the muscles in young individuals at first are in contact with each other, surround the umbilicum and run in the direction of the prepuce. In adult European bison the muscular bellies are strongly broadened (up to $14 \mathrm{~cm}$ wide in the broadest part), with a bow-shaped course directed to the exterior in a large curve. The flat terminal tendon of each of the muscles embraces, from the exterior, the liganent suspending the ostium of the prepuce and partly joins with the tendon on the other side and part of the fibres radiating into the subcutaneous tissue in the area of the ostium.

In some individuals, in addition to the bellies described, three or four bundles from cutaneus trunci muscle radiated into the region of the preputial ostium.

$M m$. praeputiales caudales are less strongly formed than the preceding. They begin in the deep fascia of the trunk and on the aponeurosis of $m$. obliquus abdominis externus at the level of the division of the pudendal external vessels. Thin muscle bellies run along the abdominal wall and radiate between the external and parietal layers of the prepuce, 5 to $10 \mathrm{~cm}$ craniad from fundus praeputii.

$M$. bulbospongiosus s. bulbocavernosus runs from the basis of the bulbourethral glands and extends along the dorsal surface of the bulbus of the urogenial canal. On the sides this muscle is bounded by $\mathrm{mm}$. ischiocavernosi. It fused with them along the whole length of contact. 
The proximal thickest and widest part of $m$. bulbocavernosus (up to $6 \mathrm{~cm}$ wide and $4 \mathrm{~cm}$ thick) protruded in front of the anterior margin of the bulbus. This part forms a cylindrical muscular prominence above the bulbus and bulbourethral glands. In the cranio-dorsal part the muscle bundles, seen from the back, take a semicircular course. Towards the radix penis the muscle becomes increasing narrow and the bundles of fibres run obliquely (Photo 20). On the dorso-caudal surface of the muscle along the median line there is a longitudinal septum. In the lower three quarters in the extension of the septum there is a longitudinal groove. The dorsal crest of the bulbus of the urogenital canal forms the continuation of the septum into the interior of the muscle.

$M$. bulbocavernosus ends, below the termination of bulbus urethrae at a distance of 4.5 to $6.5 \mathrm{~cm}$ from the line of the lower reach of the $\mathrm{mm}$. ischiocavernosi. The length of $\mathrm{mm}$. bulbocavernosi varies with the individual and depends on the length of bulbus in the sense that the muscle is always longer than it.

In our material the mean length of the muscle in adult bison was $10.2 \mathrm{~cm}$.

$M$. ischiocavernosus $s$. ischinspongiosus is strongly developed in the European bison (Photo 20). It begins on tuber ischii cauded and centrad. It surrounds crura penis and is inserted to tunica albuginea of the crura and partly of radix penis.

A bundle of fibres, the external appearance and course of which justify their being treated as independent muscles, run from $m$. ischiocavernosus. Among them is the muscle occurring in all the European bison we dissected, $m$. ischiourethralis and, in some bison, $m$. ischiobulbosus (both described together with the bulbourethral glands). In two cases ("Putnar", "Pokorny") the bundle of fibres running craniad and inserted in the median line from the dorsal surface of aponeurosis $m$. urethralis separate from $m$. ischiourethralis. On the way they participate in the formation of the "muscle sac « for the bulbourethral glands.

$M$. retractor penis $s$, rectopeninus begins with a vertebral insertion on the second, third or both coccygeal vertebrae, laterally from the vascular processes of the vertebrae. The flat tendon of this muscle emerges from under $m$. sacrococcygeus ventralis lateralis and enters under $m$. levator ani. This tendon is joined by bundles of fibres from $m$. levator ani, $m$. sphincter ani externus and in one case ("Pomruk *) from $m$. transversus perinei.

Below the anus both $\mathrm{mm}$. retractores penis are situated in a groove formed by $m$. ischiocavernosus and $m$. bulbocavernosus (Photo 20). Below the apex of $m$. bulbocavernosus where the penis is most flattened laterally, the two $\mathrm{mm}$. retractores penis approach each other. Starting 
from the proximal curve of the sigmoid flexure of the penis they are surrounded together by fascia and are located below the penis (Photo 21). At the level of the distal curve, where the penis becomes cylindrical in shape, $m m$. retractores penis are attached to the penis ventro-laterally and further run along the lateral surfaces of the penis. In the direction of the apex these muscles become increasingly thin, again pass on to the ventral surface of the penis and end in tunicae penis near the place of transition of the parietal layer of the prepuce into the prepuce proper.

\section{RESULTS AND DISCUSSION}

Little has hitherto been written on the subject of the morphology of the reproductive organs of the European bison, and in fact our knowledge of this aspect of the American bison's closest relative - Bison bison Lin n a u s, 1758 is similarly limited. In comparing the results of our own investigations we perforce made use of data contained in corresponding literature on other ruminants, chiefly cattle. This would appear to be justified on account of the abundance of literature on this species and its phylogenetic relation to the European bison.

\section{Testicles, epididymis and scrotum}

In order to check whether the views expressed by $\mathrm{O}$ w e $\mathrm{n}(1848)$ and $\mathrm{M} \ddot{\mathrm{u}} \mathrm{ller}$ (1852) on the size of the testicles in the European bison are confirmed by studies of a larger amount of material, comparison was made of the results of our own observations with data on the domestic

Table 10 .

Comparison of measurements and weight of testicles in European bison and domestic ruminants.

\begin{tabular}{|l|cc|c|c|c|}
\hline \multirow{2}{*}{ Species } & \multicolumn{2}{|c|}{ Bison bonasus } & Bos taurus & Ovis aries & Capra \\
& dextr. & sinistr. & & & \\
\hline Length mm & $87-115$ & $88-121$ & $140-170$ & 100 & $93-108$ \\
Breadth mm & $48-71$ & $45-69$ & $50-60$ & $50-60$ & $46-54$ \\
Weight $\mathrm{g}$ & $110-287$ & $96-279$ & $250-300$ & $200-300$ & $145-1 \mathrm{f0}$ \\
\hline
\end{tabular}

bull (Table 10). Data on the European bison were obtained from fixed material, and thus material with reduced dimensions and weight. $\mathrm{S} \mathrm{ch} \mathrm{u}-$ b e r t (1909) stated that linear losses in the cardiac muscles of cattle as the result of fixing are about $3 \%$. These differences undoubtedly vary 
with different organs. It is nevertheless possible to state that the length of testicles in adult European bison is far smaller that the length of testicles in the domestic bull. The breadth of the testicle in the European bison is, on the other hand, similar to the corresponding dimension in cattle. Ratios between length and breadth of testicles in the European bison thus differ from those in domestic bulis and are unexpectedly closer to the ratios found in small domestic ruminants.

Classes of variations in weight of the testicles in adult European bison are far wider than those accepted by Schwarz (1939) for the domestic bull. It is particularly the lower limit of variation which is shifted in minus, and as a result the mean weights of testicles in the bison are smaller than in domestic bulls and closer to the ratios occurring in the ram.

In the case of two European bison we were able to weight the testicles before and after fixing. Weight loss in these cases was about $4.5 \%$.The inclusion in our discussions of this loss (although the fact that only two cases were examined did not entitle us to do so) did not in principle affect the conclusions formulated above.

As can be seen from table 2 the dimensions, and particularly the weight of the testicles in adult European bison, exhibit considerable variation per individual. The material examined leads to the conclusion that the differences are not connected with body measurements (cf. data in tables 1 and 2, referring to "Pug II ", "Polamaniec", "Pokorny") but rather with age. There is not distinct predominance in size and weight between the right and left testicles.

Connective tissue elements in the testicles of the European bison are, from the point of view of macroscopic structure, moderately developed. The thickness of tunica albuginea varied from $1.05 \mathrm{~mm}$ to $1.46 \mathrm{~mm}$ (in cattle from 0.5 to $1.5 \mathrm{~mm}-\mathrm{Kröll} \mathrm{ing} \mathrm{\&} \mathrm{Grau}, 1960$ ). The thickness of the mediastinum testis, the macroscopic picture of which depends on the size and texture of connective tissue, is far smaller than in the testicles of the domestic bull. Maximum thickness of mediastinum testis near the extremitas capitata in the European bison we dissected was $4 \mathrm{~mm}$. In cattle this measurement is $6-8 \mathrm{~mm}(\mathrm{~S} \mathrm{c} \mathrm{h} \mathrm{wa} \mathrm{r}, 1939$; $\mathrm{Kr}$ ölling \& Gra u, 1960). Also the septa of the testicle running from mediastinum testis are only faintly visible macroscopically (Photo 3 ).

The testicles in both the one-day old bison calves dissected had already descended below the external inguinal ring. This is evidence that descensus testiculorum occurred in principle during intrauterine development. Taking as an example, unfortunately the only one in our material, the ten-months old "Pustybór", it might be considered that the final location of the testicles in the scrotum occurs at an age over 
ten months. According to V lote $\mathrm{n}$ (1927) this takes place far earlier in domestic bulls, at the age of about 3 months. In the European bison, as a wild living species, processes connected with the descent of the testicles would appear to last longer. It must however be pointed out that our observations in this respect refer to one individual only.

The above proviso is the more necessary in view of the fact that in three European bison disturbances were found in the process of descent of the testicles. Four-year old "Puck « exhibited bilateral cryptoorchismus, the testicles being situated within the abdominal cavity, the right at a distance of about $5 \mathrm{~cm}$ and the left just near the internal inguinal ring. The long axis of the testicles was located horizontally. Dimensions - length of right testicle $90 \mathrm{~mm}$ and left $70 \mathrm{~mm}$ - are similar to the corresponding values in normally developing testicles. The testicles covered by the peritoneum were directed with the epididymal border to the abdominal wall, and the free border inwards. Plica ductus deferentis extended to the extremitas caudata and the plica vascularis to the extremitas capitata of the testicle. The broad $m$. cremaster externus joins the covering structures of the testicles in this same place. The vaginal process penetrated to the bilateral patent inguinal canals and ended at the level of the external inguinal ring.

In ten-year old "Posusz the process of descent of the right testicle was arrested at the level of the inguinal canal. The testicle had remain$\epsilon d$ in the canal and was relatively long and narrow (Table 2). No other deviations in structure were found.

The right testicle of fourteen-year old "Pomruk « was outside the inguinal canal but had not descended into the scrotum. There was no scrotal cavity on the right side. The fundus of the right vaginal process reached the level of the collum scroti. The right testicle was irregular in shape and the dimensions of the right epididymis enormous. Both "Posusz and sPomruk covered female bison and had progeny.

If we do not take the first five European bison (Table 1) into consideration on account of the unfinished process of descent of the testicles found in them, then the figure of three developmental disturbances of this kind out of fifteen European bison must be considered as a considerable percentage. Cryptoorchismus has been recorded in all species of domestic animals and in many wild species (Ż edenov, 1965). Among ruminants this often occurs in rams (E ckste in \& $\mathrm{Zucker-}$ $\mathrm{m}$ a $\mathrm{n} n, 1956$ ), reaching as much as $12.5 \%$ in some breeds (W e $\mathrm{ndt}$ et al., 1960).

The epididymis defines the epididymal border of the testicle on the caudolateral side. This statement applies to the relations observed in cadavers. The testicles of ruminants, on account of their shape, vertical 
position and way in which they are attached, are easily revolved round the long axis. This may also occur as the result of postmortal changes (e.g. difference in tension of $m$. cremaster ext. or a position of the body different from the physiological one). The description of the position of the testicles and epididymis in the scrotum of the domestic bull based on observations made in the dissection room (repeated over a long period of years in anatomical papers and textbooks) had to be corrected after comparison with the results of examinations made on living animals. For obvious reasons it was impossible to carry out such examinations on living European bison and we were therefore obliged to content ourselves with anatomical laboratory material.

The breadths of different parts of the epididymis in cattle is given by $\mathrm{Schlumperger} \mathrm{(1954).} \mathrm{Comparison} \mathrm{of} \mathrm{these} \mathrm{data} \mathrm{show} \mathrm{that} \mathrm{the}$ head of the epididymis is far broader in the European bison. The breadth of the corpus epididymis is similar, but the clearly defined narrowing of the median part of the corpus present in cattie does not occur in European bison. Among other differences is the appearance of the tail of the epididymis. In cattle it is similar in shape to a hood protruding in the extension of the long axis of the corpus ( $\mathrm{S} \mathrm{h} \mathrm{w}$ a r $\mathrm{z}$ e, 1939) while in the European bison it is set more to the back (Fig. 2).

Both $\mathrm{S} \mathrm{chwarze}(1939)$ and $\mathrm{S} \mathrm{ch} \mathrm{lu} \mathrm{mperger} \mathrm{(1954)} \mathrm{consider} \mathrm{the}$ position of $m$. cremaster ext. in domestic animals as a feature constant to the species. In the domestic bull the muscle covers the caudal and medial surfaces of the spermatic cord ( $\mathrm{S} \mathrm{chlumperger,} \mathrm{l.c.).} \mathrm{Muscle}$ fibres end above the head of the epididymis ( $\mathrm{S} \mathrm{h}$ war $z \mathrm{e}$, l.c.). In the ram the median surfaces of the cords are not covered $(\mathrm{Schlumper-}$ g e r, l.c.). The muscle ends at the level of the head of the epididymis (S c h w a r ze, l.c.).

In the European bison relations are different. $M$. cremaster ext. covers the spermatic cords caudolaterally (Photo 2, A), leaving an uncovered cranial and median surfaces. The position of the other component elements of the cords and the previously discussed situation of the epididymis in relation to the testicles creates a situation in the case of the European bison in which the testicles together with the spermatic cords are revolved by about $90^{\circ}$ in comparison with cattle. The swing on the left side took place to the right, and on the right side to the left round the long axis. Does this correspond to the situation of the testicles and spermatic cords in living European bison? An argument against accepting the above-mentioned situation as physiological is formed by the fact that it is similar to the earlier description of relations in cattle (M a r tin-Schauder, 1938; Schwarze, 1939; Ellenberger-B a u $\mathrm{m}, 1943$ ) which proved to be different from that established by 
examinations of live animals ( $\mathrm{Schlumperger,} \mathrm{1954;} \mathrm{Nickel} \mathrm{et}$ al., 1960). It may therefore be considered by analogy that the case is similar in the European bison. On the other side the following argue in favour of the position of the testicles in the European bison being different from that in the domestic bull: a) the fact that the left testicle is shifted forwards in front of the right and the differences in the shape of the scrotum, b) the difference in the extent of $m$. cremaster externus.

The scrotum in European bison is set further caudad in comparison with the relation found in domestic bulls. It is also shorter than in bulls, which would agree with the general principle in the group of animals with a "parapenial " type of scrotum, according to which the length of the scrotum increases with increasing distance from the anus (Źdenov, 1965). In European bison up to the age of three the scrotum is very short, with faintly marked shift forwards of the left part. In adult European bison it is more pendulous and the forwards shift of the left part is more distinct. As a result the longitudinal grooves along raphe scroti are located not cranially and caudally as in the domestic bull, but the anterior groove deviates to the right and the posterior to the left. The whole gives the impression of lateral flattening, which is due on the one hand to the caudal situation of the scrotum itself, and on the other to the narrow spacing of the European bison's hind limbs.

This location of the scrotum would seem to be of advantage under natural living conditions. The high suspension reduces the danger of injury when the animal makes its way through dense undergrowth, while the legs form some protection for the scrotum from the sides.

\section{The genital accessory glands}

Our description of the structure of the ampulla ductus deferentis in the European bison in principle corresponds to the description given by $\mathrm{K} \mathrm{rolling} \mathrm{(1930),} \mathrm{with} \mathrm{the} \mathrm{exception} \mathrm{of} \mathrm{the} \mathrm{remarks} \mathrm{as} \mathrm{to} \mathrm{the} \mathrm{size} \mathrm{of}$

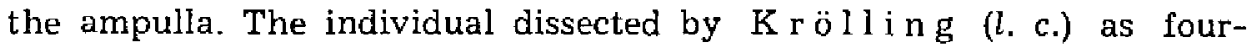
-years old belonged to animals with incomplete growth process and the $70 \mathrm{~mm}$ length of the ampulla does in fact come within the limits accepted for the ram $(60-80 \mathrm{~mm}-\mathrm{Schummer} \& \mathrm{Nickel}, 1960)$. In our material ampullae ductuum deferentium with similar measurements were found in European bison two and three years old. In European bison from five to ten years old this dimension is greater and comes within the limits accepted for cattle $(80-150 \mathrm{~mm}-\mathrm{Nickel}$, 1954). Thus not only the structure but also the length of ampullae in the European bison is similar to that in domestic cattle. 
Vesiculae seminales do not differ in either structure or position from those in cattle. The slight development of these glands in the European bison which $M$ ülle $r$ (1852) described cannot in any case be considered as a character of the species. Krölling (1930) also adopted this standpoint. The dimensions he gives (length $100 \mathrm{~mm}$, breadth $25 \mathrm{~mm}$ ) are similar to the mean values which we obtained (cf. Table 6) and come within the limits accepted for cattle (length $70-120 \mathrm{~mm}-\mathrm{N}$ i c$k e 1,1954)$. The absence in the European bison of the flexures of the caudal parts of these glands typical of cattle reported by $\mathrm{Kr}$ olli ing (l. c.) is due to the fact that the European bison which he dissected was not fully grown. In bison over five years old the flexures on the exterior of the terminal parts of the glands are visible (Photo 6, 7).

The prostate in the European bison is formed both in the external part - the corpus and in the internal - pars disseminata prostatae. The mean transverse measurement of the corpus is similar, and the longitudinal measurements slightly smaller, than the dimensions given by Nickel (1954) for these glands in the domestic bull (transverse about $30 \mathrm{~mm}$, longitudinal about $10 \mathrm{~mm}$ ). The results of our observations on the extent and measurements of pars disseminata prostatae in the European bison correspond to the relations in bulls described by $\mathrm{G} \mathrm{ra-}$ bowski (1937).

The European bison's bulbourethral glands are situated on the dorsal side of the male urethra, near the medial line, and thus are similar to those in small domestic ruminants, particularly the ram ( $\mathrm{G} \mathrm{rabow}$ $\mathrm{sk} \mathrm{i,} \mathrm{l.c.).} \mathrm{In} \mathrm{the} \mathrm{male} \mathrm{goat} \mathrm{these} \mathrm{glands} \mathrm{are} \mathrm{shifted} \mathrm{more} \mathrm{to} \mathrm{the} \mathrm{side,}$ and this is even more marked in the domestic bull ( $\mathrm{G} \mathrm{r} \mathrm{abow} \mathrm{ski,l.c.)}$. In our material the mean length of the gland in adult European bison was $21 \mathrm{~mm}$ and breadth $27 \mathrm{~mm}$. According to $\mathrm{N} \mathrm{i} \mathrm{ckel} \mathrm{(1954)} \mathrm{the} \mathrm{length}$ of the bulbourethral gland in cattle varied from 40 to $50 \mathrm{~mm}$ and width about $25 \mathrm{~mm}$. Measurements of breadth, on account of the differences in the situation and the fusion of the two lobes, and in consequence in the way in which the measurement is made (cf. Fig. 1-D), cannot be directly compared. On the basis of comparable data on length of the glands, bearing in mind the fact that the breadth we give applies to both lobes, we can state that the bulbourethral glands are far smaller in the European bison than in cattle.

\section{Uterus masculinus}

The uterus masculinus in European bison was described for the first time by $M$ ülle $r$ (1852). The undivided part of the organ was $\gg 41 / 2$ inches long " and the strongly developed horns reached almost to the 
testicles. The lumen of the uterus was connected with the lumen of the urogenital canal through an ostium on colliculus seminalis.

Leisering (1890) also found the uterus masculinus in an European bison calf. In the two individuals which he dissected one had this organ highly developed, while the other exhibited relations similar to cattle.

The uterus masculinus described in European bison by $\mathrm{Krölling}$ (1930) differed from the case described by M üller (1852) primarily as to dimensions, absence of horns and blind cranial end. $\mathrm{Kröll}$ ing did not find any recessi or processes which would form evidence of the vestige of paired Müllerian ducts. Detailed examination of the microscopic structure of serial sections of the organ, which was $105 \mathrm{~mm}$ in length, enabled the author to distinguish several parts. They correspond to pars cervicis uteri, pars uterina vaginae, vagina propria et pars vestibularis vaginae. Using data taken from studies by $M$ ül I e $r$ (l. c.) and L e i s e r ing (l. c.), and on the basis of his own investigation, $\mathrm{Krölling} \mathrm{(l.c.)} \mathrm{discusses} \mathrm{in} \mathrm{greater} \mathrm{detail} \mathrm{the} \mathrm{question} \mathrm{of} \mathrm{the}$ occurrence of uterus masculinus in the European bison. In conclusion he states that wout of the four male European bison so far examined in three there was distinct mixing of sexual characters differing from similar anomalies in other mammals. They must be considered as degenerative characters due to in-breeding*.

Our observations increase the number of European bison in which the uterus masculinus has been found so far to twenty two ${ }^{3}$ ), which among the twenty four examined in this respect forms $92 \%$ of all cases.

According to $\mathrm{Schmaltz}$ (1911) and Lenk (1913) uterus masculinus does not occur in domestic ruminants, or at least has not been found, although Disselhorst (1904) considers the goat and stag as species in which this organ may attain its greatest development. $\mathrm{S}$ k od a (1917), in checking which of the views is correct, found the presence of vestiges of Müllerian ducts in $71 \%$ of the domestic bulls examined, all the buffalo examined and in five rams. He considers the vesicular form of the uterus masculinus the most fraquent. In his introduction to his study Skoda (l. c.) polemises with $\mathrm{M}$ üll e r (1852) regarding the character of uterus masculinus in the European bison, considering the case described by Müller (1852) as an anomaly of the gynemasty kind. Swoboda (1921) confirms the results of Skoda's studies (l. c.) supplementing them with the effect of age and castration on the occurrence, size and appearance of uterus masculinus in domestic ruminants.

j) The presence of uterus masculinus was also noted in "Storper $879 \%$, Zona $1454 \%$ and $"$ Pudzik«, the organs of which were not included in the material elaborated in this study. 
It is clear from the data given above that the occurrence of the residua of Müllerian ducts in the genital system of male Bovidae is not a rare phenomenon. The European bison would thus not form a special exception if it were not almost a rule and if the degree of formation of these organs which in other species are rudimentary, were not so considerable.

The large dimensions of uterus masculinus and its connection with canalis urogenitalis resulted in $\mathrm{Krölling} \mathrm{(1930)} \mathrm{terming} \mathrm{the} \mathrm{case}$ described by $\mathrm{M}$ üller (1852) as "a typical hermaphrodite*. The drawing and description of the uterus given in M üller's study $(l$. c.) shows that it can be allocated to the third of the types we have distinguished (Fig. 3-C).

We thus have grounds for stating that residua of embryonic Müllerian ducts occurred, and over a considerable distance, in the great majority of the male European bison so far examined. The degree of their continued development may differ up to the stage, which, from the aspect of external shape, is similar in appearance to the internal genital organs of the female. This advanced development, when we can distinguish macroscopically parts corresponding to the vagina, two-horned uterus and even the oviduct, is an equally frequent phenomenon (cf. Fig. 3-A, C).

We have no grounds for deliberating on whether the European bison calf described by Leisering (1890) was fully capable of siring progeny, but $\mathrm{Krölling} \mathrm{(1930)} \mathrm{considers} \mathrm{the} \mathrm{male} \mathrm{European} \mathrm{bison}$ which he dissected as having attained reproductive function. All the European bison which we examined came from animals kept in a reserve and thus their sexual activity was of necessity limited (and in some cases completely eliminated), nevertheless several of them sired progeny. Among males with type $A$ uterus the following three bison sired progeny: "Pokorny , "Plamiec $"$ and "Pomruk $\alpha$. One bison in each group with type $B$ and $C$ uterus: "Posusz and $» P u g$ II . European bison with type $D$ and $E$ uterus did not have any progeny. In view of the similarity in the structure of genital organs in "Müller's European bison * and "Pug II" and the fertility of the latter we may assume that "Müller's European bison « was not a hermaphrodite as $\mathrm{Kr}$ öll ing (1930) judged it to be.

Thus even advanced development in male European bison of the derivates of Müllerian ducts did not significantly affect their fertility.

In order to obtain a complete picture of the connections between uterus masculinus and the fertility of the male European bison it would sppear essential to draw attention to the absence of progeny in individuals of which one had an only very slightly developed uterus and 
the second had none at all (Fig. 3-D, E; Table 7). This was connected with causes of a different nature. "Polamaniec disclosed pathological changes in the hip joint ( $\mathrm{Pil}$ a r ski, 1956) which made it impossible for it to jump when covering a female. »Pozew " was transferred to the reserve at Smardzewice when two years old and had no contact with female bison.

$\mathrm{K} r$ ölling (1930) considers the effect of in-breeding as the cause of the mixing of sexual characters. This factor undoubtedly operated at the time $F$. M ülle r and L e is e ring wrote their studies and became even more significant after the first world war, when the number of European bison surviving in the whole world did not exceed 50 individuals (Krysiak, 1967). On the other hand, however, the phenomenon of occurrence in males of derivates of Müllerian ducts of advanced development was found in great numbers of cases in such mammals as the European beaver (Freye, 1953) and Canadian beaver (C o n a v y, 1958). It would be difficult to ascribe this to the effect of circumstances similar to in-breeding in the case of either species.

\section{Penis}

The penis of the European bison, as in other ungulates, is of the fibro-elastic type. Our observations confirm the remarks made by M üller (1852) that the sigmoid flexure of the penis is only faintly marked in the European bison. This applies particularly to the distal curve of the sigmoid flexure. The structure of corpus penis in respect of macroscopical structures corresponds to the relations described by Preuss (1954) in domestic cattle.

Bulbus canalis urogenitalis in the European bison is more compact in structure than would appear to be the case from the description given of the bulbus in the domestic bull ( $\mathrm{Grabowski}$, 1937). In the European bison there is no median groove on the dorsal surface of the bulbus, dividing it into two crura. On the contrary there is a sharp crista in this place which dorsad passes into a septum dividing the bilateral mm. bulbocavernosi. Grabowski (l. c.) describes and illustrates this sharply bordered shape of the bulbus, as typical of the male goat.

The position of the pars penis canalis urogenitalis together with corpus cavernosum in relation to corpus penis is similar in the European bison to that in cattle.

Apex penis on the dorsal side, and near the galea glandis on the dorsolateral side (left) has a dense bundle of connective tissue fibres. In the domestic bull it was defined by $\mathrm{M}$ äd e r (1907) and $\mathrm{S} \mathrm{ch} \mathrm{mal} \mathrm{tz}$ 
(1919) as a component part of tunica penis. By Preuss (1954) it was termed ligamentum apicale penis and included in the composition of tunica albuginea penis. The position of this part of the penis in European bison is similar to that in the domestic bull, except that the variations described in the latter by Preus (l. c.) were not found. The external appearance of apex penis in the European bison permits of including it in Gerhard's plan (1933) classifying the penis of ruminants in the type closest to that accepted for the genus Bos.

Table 9 shows that in European bison calves from one day to ten-months old the penis is relatively short. This is most clearly seen in the ten-months old "Pustybor". In older European bison the situation changes in favour of the penis and is maintained on a similar level in all European bison regardless of age. It may therefore be concluded that while the increase in body measurements is at first more rapid than the increase in length of the penis, after the age of ten months the penis elongates. Its length then remains in a certain approximately constant ratio to the external body measurements (cf. Table 9).

This applies both to the ratio of length of penis to dimension $F$, which in a certain sense corresponds to the length of the abdominal integument. The proportionately short penis in young bison may therefore be the cause (apart from adhesion of the layers of the prepuce) of the penis not protruding from the prepuce during defaecation, which is a characteristic of adult bison ( $\mathrm{J}$ a c z e w s k i, 1958).

In his studies of the postnatal development of penis and prepuce in domestic bulls Ashdown (1960) distinguished five successive stages of this development. Complete separation of the layers of the prepuce and complete elongation of the penis, according to this author, takes place in young bulls between the ninth and eleventh month of life. The appearance of apex penis in ten-months old "Pustybor " (Photo 18) corresponds to the stage described for four to six-months old domestic young bulls. This may form evidence of the slower development of the European bison in this respect also.

In our material the mean length of the penis in adult European bison was $86.4 \mathrm{~cm}$. In domestic cattle this dimension varies from 90 to 100 $\mathrm{cm}$ ( $\mathrm{Schummer} \& \mathrm{Nickel}, 1960$ ). Bearing in mind the effect of fixing it may be said that the length of penis in European bison comes within the limits accepted for cattle.

5. The preputial and extrensic penile muscles

The preputial muscles correspond in respect of both insertions and course to the respective muscles described by Brauell (1868) in 
domestic ruminants. The marked broadening and semicircular course of $\mathrm{mm}$. preputiae craniales similar to that which we described in European bison was found by $\mathrm{Br}$ a u eIl $(l . c$.) only in the case of the ram.

$M$. bulbocavernosus is in principle similar in structure to that in domestic ruminants. It is shorter than in the domestic bull, in which it attains lengths up to $18 \mathrm{~cm} \mathrm{(} \mathrm{He}$ i n e $\mathrm{man} \mathrm{n}, 1937$ ), but is broader and thicker. This is undoubtedly connected with the dimensions and structure of the bulbus urethralis, previously mentioned.

The $m m$. ischiocavernosi, strongly developed in the European bison, surround $m$. bulbocavernosus from the sides, forming two oblique grooves running length ways. The bilateral $\mathrm{mm}$. retractores penis are situated in these grooves (Photo 20). They are separated from each other at this level. This arrangement, such as described above in the European bison of the various muscles of this region in relation to each other, was described in the case of domestic ruminants by $\mathrm{He}$ inemann (1937) in the case of the male goat. According to $\mathrm{He}$ ine$\mathrm{m}$ a $\mathrm{n} \mathrm{n}\left(l_{+} \mathrm{c}.\right)$ in the male goat the bilateral $\mathrm{mm}$. retractores penis retain their independence in their further course also, while in the European bison below radix penis these muscles behave as they do in domestic bulls.

\section{REFERENCES}

1. Ackerknecht E., 1943: Das Eingeweidesystem. [In: Ellenberger-Baum Handbuch der vergl. Anat. der Haustiere]: 522-544. Springer Verlag, Berlin.

2. Ashdown R., 1960: Development of penis and sheath in the bull calf. J. Agricult. Science, 54, 3: 340-352. Cambridge Univ. Press.

3. Bojanus L. H., 1827: De uro nostrate eiusque sceleto. Nov. Acta Akad. Leopold. Carol., 13: 411-478. Bonnae.

4. Bra uell H., 1868: Myologie der männlichen Genitalien. Vjschr. wiss. Veterinärkd., 29: I-27. Wien.

5. Buchholtz O, 1951: Zum Bau des Peniskörpers beim Pferde und seine funktionelle Bedeutung. Diss. Hannover.

6. Conavay C., 1958: The uterus masculinus of Castor canadensis. J. Mamm., 39: $97-108$.

7. Dis sel hor $\$ t$ R, 1904: Ausführapparat und Anhangsdrüsen der männlichen Geschlechtsorgane. [In: Oppels Lehrbuch der microskop. Anat. Wierbeltieren $\ll$ ], 4 (acc. to $W$ a 1 te $n, 1965$ ).

8. Eckstein P. \& Zuckermann J., 1956: Morphology of the reproductive tract. [In: Marshall's physiology of reproduction«], 1, 1: 43-174. Longmans Green and Corp. London-N. York.

9. Fr e y e H., 1953: Bemerkungen zum Genitalsystem des Bibers. Wiss. Z. Martin Luther Universität., 2: 911-915.

10. Gerhardt U., 1933: Kloake und Begattungsorgane. [In: wHandbuch der vergl. Anat. der Wierbeltierek], 6: 314-347. Urban \& Schwarzeberg. BerlinWien. 
11. Grabowski K., 1937: Uber Schwellräume der Harnröhre der männlichen Haussäugetiere. Diss., Hannover.

12. He i ne ma n n K., 1937: Einigen Muskeln des männlichen Geschlechtsapparates der Haussäugetiere $-M$. bulbocavernosus, $m$. ischiocavernosus, m. retractor penis. Diss. Hannover.

13. Jaczewskj Z., 1958: Reproduction of the European bison, Bison bonosus (L.), in reserves. Acta theriol, 1, 9: 333-376.

I4. KI Ölling O., 1930: Uber Uterus masculinus, sowie einige Artmerkmale im männlichen Genitalapparat des europäischen Wisent (Bison bonasus L.). Ztschr. f. mikroskop-anat. Forsch., 20, 3/4: 557-583. Leipzig.

15. Krölling O. \& Gra u H., 1960: Lehrbuch der Histologie und vergleichenden mikroskopischen Anatomie der Haustiere: 315-354, Parey, Berlin.

16. Krysiak K., 1967: The history of the European bison in the Bialowieza forest and the results of its protection. Acta theriol. 12, 19: 323-331.

17. Leis ering A. G. T., 1890: Eingeweidelehre [In: "Gurlts Handb. der vergl. Anatomie der Haussäugetiere a), 7 Aufl. (acc. to Krölli ing, 1930).

18. Le nk H. J., 1913: Zur Anatomie und Histologie der Harnblase und Pars pelvina der Harnröhre der Haussäugetiere. Diss. Dresden.

19. Martin P. \& Schauder W., 1938: Anatomie der Haustiere. 3: 280-301. Schickhardt und Ebner Verl., Stuttgart.

20. Mäder E., 1907: Zur Anatomie der Glans penis der Haustiere. Archiv f. wiss. u. prakt. Tierheilkde, 33: 137-188; 281-311. Verlag Hirschwald, Berlin.

21. M üller F., 1852: Bemerkungen über den Auerochsen... Vjschr. wiss. Veterinärkde, 2: 110-133. Berlin.

22. Nickel R., 1954: Zur Topographie der akcessorischen Geschlechtsdrüsen bei Schwein, Rind und Pferd. Tierärztl. Umschau, 9, 21/22: 1-12. Konstanz a. B.

23. Owen R., 1848: Notes on the anatomy of the male Auerochs (Bison europeus). Proc. zool. Soc. Lond., 16: 126-133.

24. Pi ękoś M., Pilarski W. \& Roskosz T., 1958: Obserwacje nad drugością jelita u żubra (Bison bonasus L.). Folia morphol., 9, 1: 69-79. Warszawa.

25. Pilarski W., 1956: Deformacje szkieletu obserwowane na sześciu okazach żubra, Bison bonasus (L.). Folia morphol., 7: 301-306. Warszawa.

26. Pilarski W., Serwatka $S_{\text {, }}$ S wiézýnki K. \& Węgrzyn M., 1967: New attemps at fixing anatomical material of large mammals. Acta theriol., 12, 31: 453-458.

27. Pilarski W., 1967; Uklad moczowy zubra, Bison bonasus (L i n n a us 1758), Diss. Warszawa.

28. Preus S F., 1954: Die Tunica albuginea penis und ihre Trabekel bei Pferd und Rind. Anat. Anz., 101: 64-83. Jena.

29. Roskos z T. \& Empel W., 1963: Das Skelett der Gliedmassen des Wisents, Bison bonasus ( $\mathrm{L}$ in $\mathrm{n}$ a e us, 1758). Acta theriol., 7, 13: 259-300.

30. Schlumperger O. R., 1954: Der Nebenhoden und seine Lage zum Hoden. Diss., Hannover.

31. Schmaltz R., 1909: Penis. Berliner tierärtzl. Wschr., 25: 455-458.

32. Schmaltz R., 1912: Die Geschlechtsorgane. [In: „Ellenberger - Hdb. vergl. mikroskop. Anatomie der Haustiere«], Zweite Aufl., Berlin. (acc. to $\mathrm{Sk} \circ \mathrm{da}, 1917)$.

33. Schubert F., 1909: Beitrage zur Anatomie des Herzens der Haussäugetiere. Diss., Dresden. 
34. Schummer A. \& N icke 1 R., 1960: Lehrbuch der Anatomie der Haustiere, 2: 338-345. P. Parey, Berlin-Hamburg.

35. Schw a r z e E., 1939: Hoden und Nebenhoden. Tierärztl. Wschr., 47, 19: 291298. Wien.

26. $\mathrm{Skoda}$ K., 1917: Untersuchungen über das Vorkommen Uterus masculinus bei einigen Wiederkäuern (Bos taurus, Bos bubalus und Ovis aries). Anat. Anz., 50: 111-120. Jena.

37. Sw oboda A., 1929: Beitrag zur Kenntnis des Utriculus masculinus der Haustiere. Ztschr. Anat. Entwicklugs-gesch., 89: $494-512$.

38. V 1 ot e in J. G. S., 1927: Entwicklungs des Hodens und das Urogenitalverbindungs des Rindes. Diss., Utrecht (acc. to $\mathrm{M}$ a I $\mathrm{t}$ in \& $\mathrm{S} \mathrm{ch}$ a $\mathrm{u} d \mathrm{der}, 1938$ ).

39. Walt on A., 1965: The male genital tract. [In: *Marshall's physiol. of reproduction"] 1, 2: 133-142. Longmann Green Co., London.

40. Wendt K., Pohl J. \& Mrosk H., 1960: Kriptochismus des Schafes und seine wirtschaftiche Bedeutung. Arch. Tierzucht., 3, 5: 440-458. Berlin.

41. Ż e de nov V. H., 1965: Anatomia domašnih životnih., 2: 311-360. Izd. Vyžšaja Skola. Moskva.

Received, June 25, 1968.

Warsaw Agricultural University, Department of Animal Anatomy, Wárszawa, Grochowska 272.

\section{Krzysżtof SWWIEŻYÑSKI}

\section{UKEAD PECIOWY SAMCZY ZUBRA}

\section{Streszczenie}

Praca dotyczy badań nad anatomią narząów układu plciowego samczego żubra - Bison bonasus L. W oparciu o preparacje 20 zwłok osobników różnego wieku (Tabela 1). Określono wymiary i ciężar jąder (Tabela 2) oraz ich ksztalt i polożenie (Fot. 2 do 4). Ustalono odpowiednie dane odnośnie najądrzy, nasieniowodow, gruczolów płciowych dodatkowych, cewki moczowopłciowej i prącia (Tabele 3 do 6 i 8 do 10 oraz Fot. 14 do 18). Stwierdzono występowanie u samców żubra uterus masculinus (Tab. 7, Ryc. 3 oraz Fot. 5 do 13). Brak widocznej zależności między stopniem rozwoju tej ostatniej a wyksztalceniem któregokolwiek z pozostalych narządów ukladu plciowego oraz zdolnością rozrodcza samców omawianego gatunku. Opisano budowę moszny, napletka i mięśni topograficznie i czynnościowo zwizzanych z ukladem rozrodezym (Fot. 1, 19-21).

W porómnaniu z bydlem domowym jądra żubrów doroslych są bardziej kuliste a ich sredni ciężar jest niższy. Najądrza mają silnie wyrażona, szeroka glowę i zgrubialy odsadzony ku tylowi ogon. Wśród gruczołów pleiowych dodatkowych gruczoly opuszkowo-cewkowe różnią się polożeniem i sa mniejsze od takowych u byđla. Moszna żubra usytuowana jest bardziej tylnie, jest stosunkowo krótka - siabo zaznaczonej szyjce. Lewa częśc moszny wraz z jąrem wysunięta jest lekko ku przodowi. Zagięcie esowate prącia jest słabiej zaznaczone. 


\section{EXPLANATION OF PLATES XV-XIX}

Plate XV.

Photo 1. Position of the scrotum in the European bison ("Pomruk", about 9 years old). View from left side.

a - testis sinistr.; b - testis dextr.; c - papillae uberis.

Photo 2. Cross-sections of scrotum and testicles of the European bison (»Pomruk «, about 9 years old).

A - at level of neck: B - mid-Iength: C - near apex scroti. a - m. cremaster ext,; b - caput epididymidis; c - ductus deferens; d - septum scroti; e - mediastinum testis; $\mathrm{f}$ - corpus epididymidis; $\mathrm{g}$ - cauda epididymidis.

Photo 3. Longitudinal section of left testis of European bison ( Pug II«, about 6 years old).

a - caput epididymidis; $\mathrm{b}$ - cauda epididymidis; $\mathrm{c}$ - mediastinum testis.

Photo 4. Cross-section of cauda epididymidis of the European bison (\$Pustelnik , about 8 years old).

Plate XVI.

Photo 5. Urogenital organs of the European bison ( Puzon $\propto$, about 5 years old). Pars pelvina of the system seen from ventral side: bladder deflected, a - testis; b - pars vascularis funfcuti spermatici; c - ductus deferens; $d$ - »band o consisting of the restidua of the cranial part of Müllerian duct: e - cornu; $f$ - pars indivisa uteri masculini; g - ampulla ductus deferentis; $f-g l$. vesicularis: $\mathrm{i}$ - plica urogenitalis (excised); $\mathrm{j}$ - vesica urinaria; $\mathrm{k}$ - pars pelvina urethrae; 1 - crus penis; $m$ - truncus penis (artificially bent in order to include the whole in the photograph).

Photo 6. Pars pelvina of the urogenital system of the European bison in situ ( $\$$ Pokorny 4 , about 9 years old). View from dorsal side.

A - os ilium; B - spina ischiadica: C - tuber ischiadicum; a - pars indivisa uteri masculini; b-ampulla ductus deferentis dextra; $c-g l$. vesicularis sinistra; $\mathrm{d}$ - corpus prostatae; e - pars pelvina urethrae; $\mathrm{f}$ - muscles of the bulbourethral glands; $\mathrm{g}-m$. ischiourethralis; $\mathrm{h}-m$. ischiocavernosus; $\mathrm{j}-\mathrm{m}$. bulbocavernosus.

Photo 7. Isolated uterus masculinus of the European bison (sPomruk «) together with neighbouring organs.

View from: A - dorsal side; B - ventral side; a - sband - residua of cranial part of Müllerian duct; b- cornu uteri sinistr.; c, d, e - cranial, median and caudal parts of pars indivisa uteri; $\mathrm{f}$ - ductus deferens dextr.; $\mathrm{g}$ - gl. vesicularis dextr.; $\mathrm{h}$ - urether dextr.; $\mathrm{i}$ - vesica urinaria.

\section{Plate XVII}

Photo 8. Cross-se ption of internal layer of cornu uteri masculini of the European bison. Magn. approx. $70 \times$.

Photo 9. Cross-section of mucous membrane gland of uterus musculinus of the European bison. Magn. approx. $140 \times$.

Photo 10. Cross-section through internal layers of median part of uterus masculinus of the European bison. Magn. approx. $70 \times$. 
Photo 11. Epithelium of the part of uterus masculinus shown in Photo 10 - magn. approx. $140 \times$.

Proto 12. Cross-section through internal layers of terminal part of uterus masculinus of the European bison. Magn. approx. $40 \times$.

Photo 13. Epithelium and true mucous membrane of the part shown in photo 12. Magn. approx. $100 \times$.

\section{Plate XVIII.}

Photo 14. Cranial part of dorsal wall of pars pelvina canalis urogenitalis of the European bison ("Polamaniec $\propto$, about 9 years old).

Upper pins indicate site of ostia ductuum deferentium: lower ostium uteri masculini. a - colliculus seminalis; $\mathrm{b}$ - the opening of excretory ducts of prostate; c - urethra proptia; d - pars distalis cristae urethralis.

Photo 15. Urogenital organs in the European bison (oPluszeza, about 10 years old) region of arcus ischiadicus $m$. bulbocavernosus removed, also crura penis together with $m$. ischiocavernosus. View from right side.

a - terminal part of pars pelvina urethrae; b - gl. bulbourethrales; $\mathrm{c}-$ dorsal and lateral cristae of bulbus urethralis; e - radix penis.

Photo 16. Cross-sections of pars pelvina canalis urogenitalis in the European bison ("Pomruk*, about 14 years old). Distance between sections about $1 \mathrm{~cm}$.

a - excretory ducts of the vesicular glans; b - corpus prostatae; $c$ - colliculus seminalis; d - pars disseminata prostatae; e - corpus cavernosum urethrae; $f$ m. urethralis.

\section{Plate XIX.}

Photo 17. Cross-sections: A - of crura and radix; $\mathrm{B}-$ truncus; $\mathrm{C}-$ apex penis in the European bison ("Pomruk", about 14 years old). Distance between sections - from 1 to 7 about $1 \mathrm{~cm}, 8-9$ about $12 \mathrm{~cm}, 11$ to $13-$ about $6 \mathrm{~cm}, 14$ to 17 about $2 \mathrm{~cm}, 18$ and 19 about $0.5 \mathrm{~cm}$.

a - crus penis; b - corpus cavernosum penis; c - pars penis urethrae surrounded by corpus cavernosum; d, e - external and internal layer of tunica albuginea; $\mathrm{f}$ - trabeculae corporum cavernosum penis form a scentrum«; $\mathrm{g}$ - lig. apicale penis.

Photo 18. Apex penis in a 10-month old European bison ("Pustybór*). Prepuce partially pushed back.

a - galea glandis; b - the connections between preputial layers.

Photo 19. Apex penis of the European bison (sPomruk*, about 14 years old). Prepuce transected along ventral wall.

A - raphe praeputii; e - orificium urethrae externum.

Photo 20. The extrensic penile muscles in the European bison ("Pokorny», about 15 years old).

View from posterior: a $-m$. retractor penis; $\mathrm{b}-m$. ischiocavernosus; $\mathrm{c}-m$. bulbocavernosus.

Photo 21. Isolated penis of the European bison ("Pokorny $*$, about 14 years old). a - pars pelvina urethrae; $\mathrm{b}-m$. ischiocavernosus; $\mathrm{c}-m$. retractor penis; $\mathrm{d}$ - apex penis. 


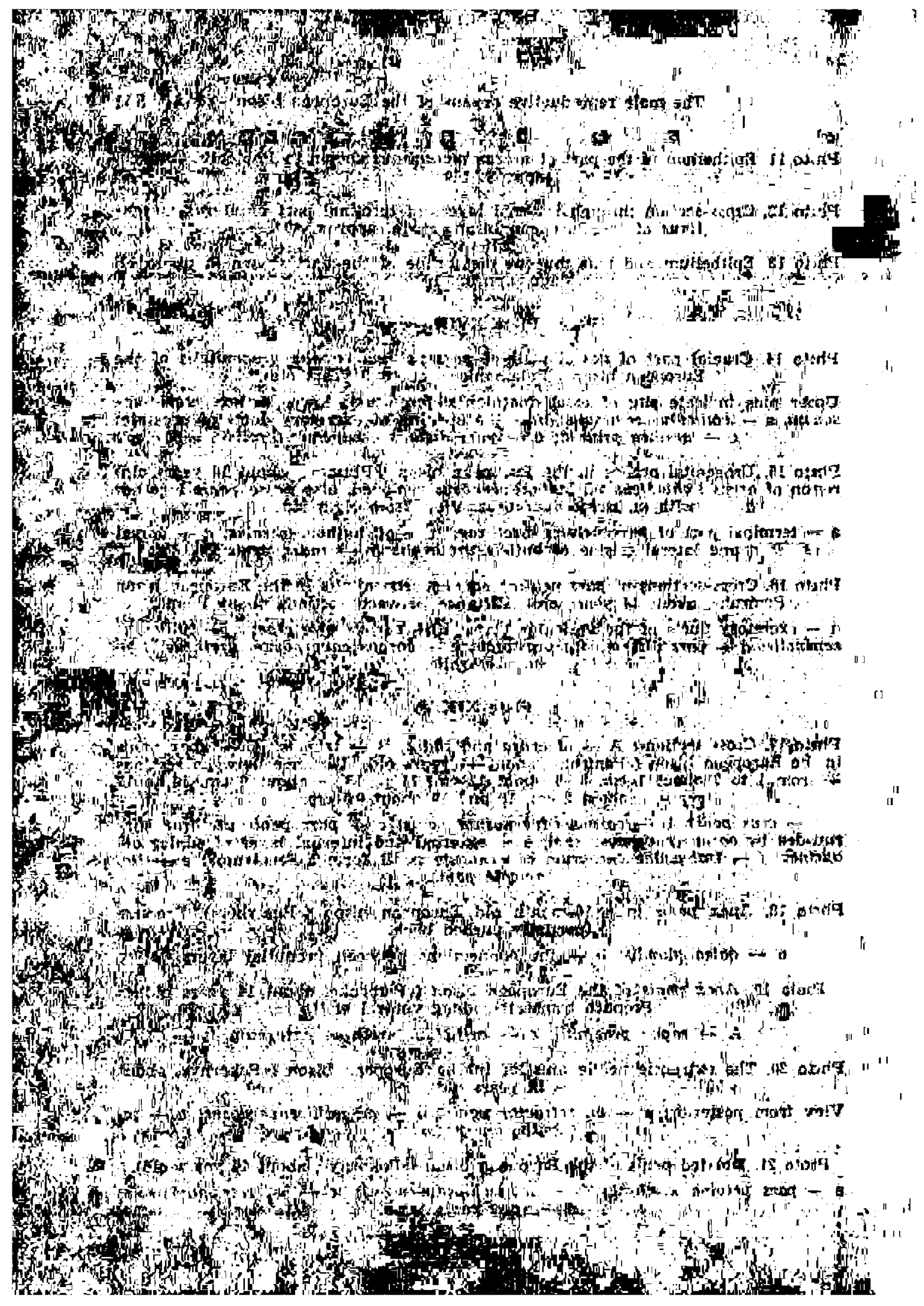




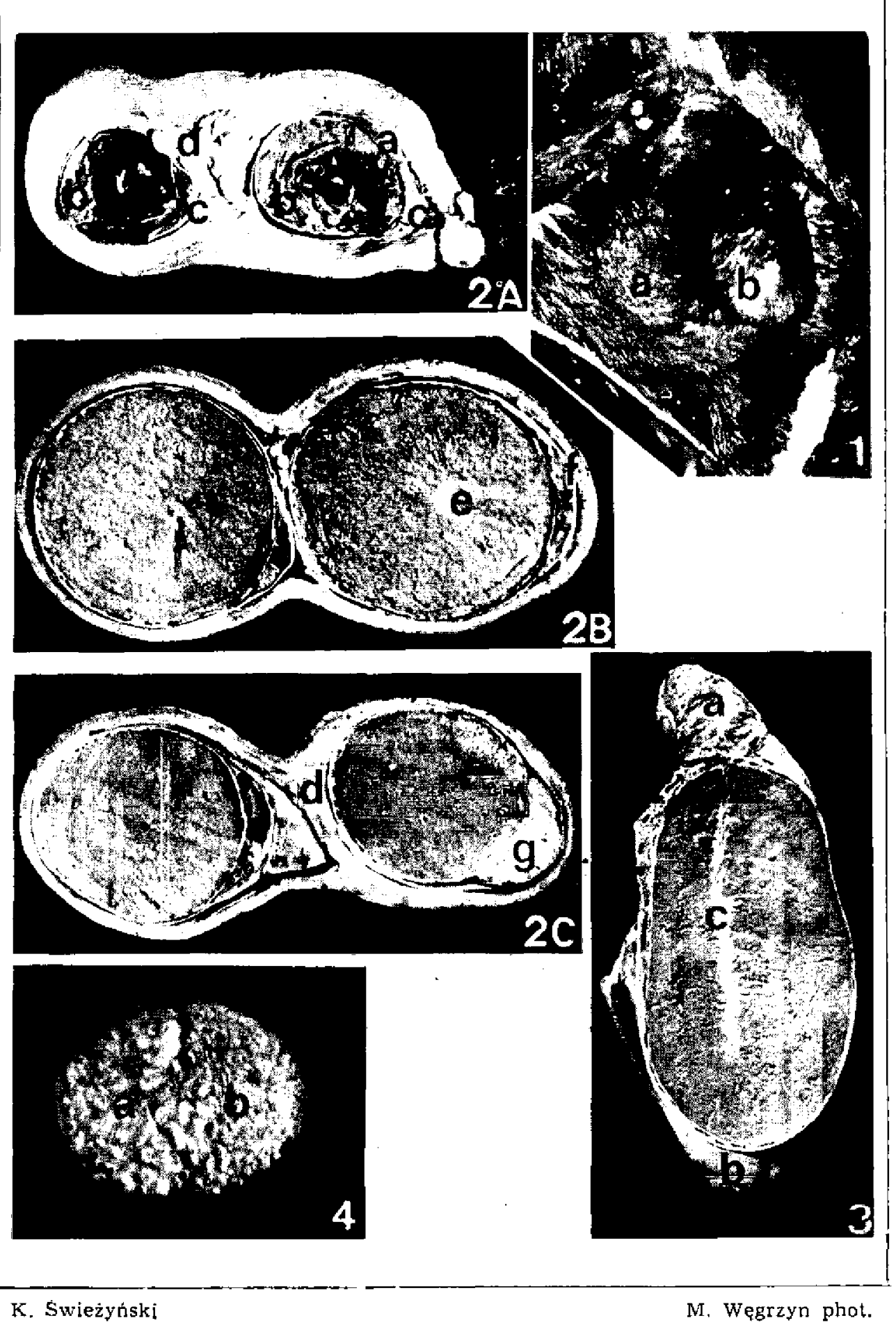



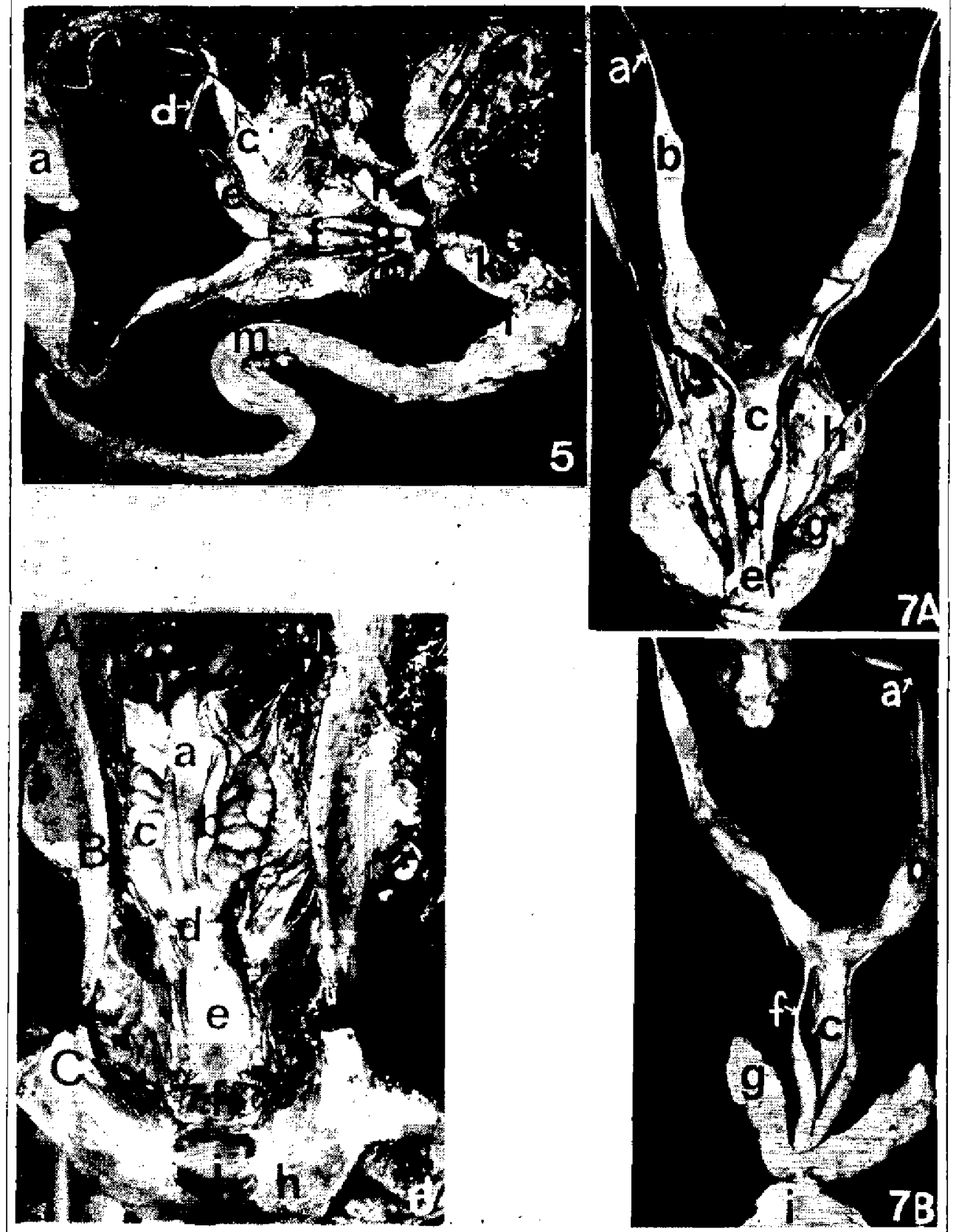

K. Swieżyńskj

S. Pytel (7) \& M. Wegrzyn phot. 


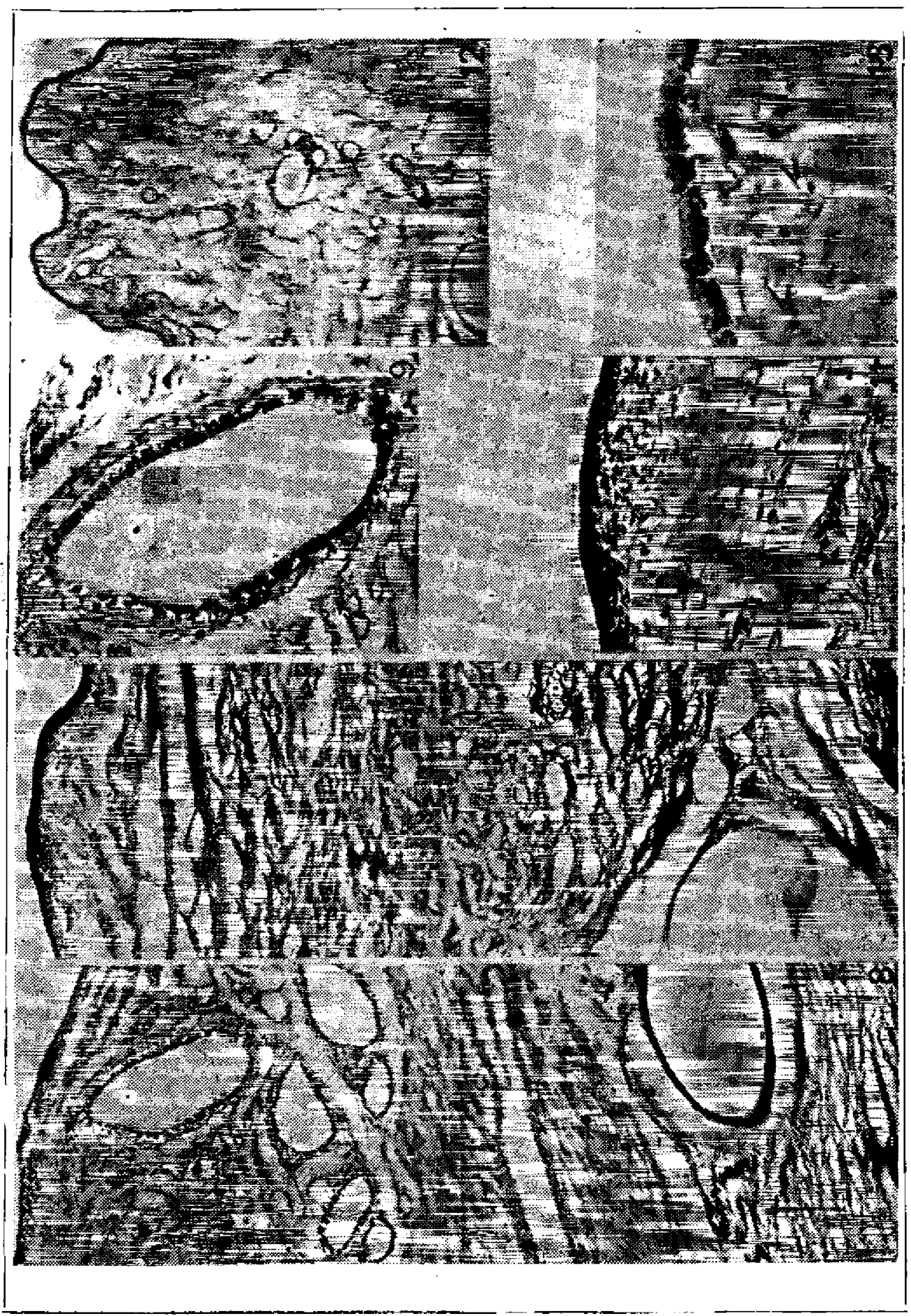

K. Swieżýnski

S. Pytel (9) \& M. Węgrzyn phot. 

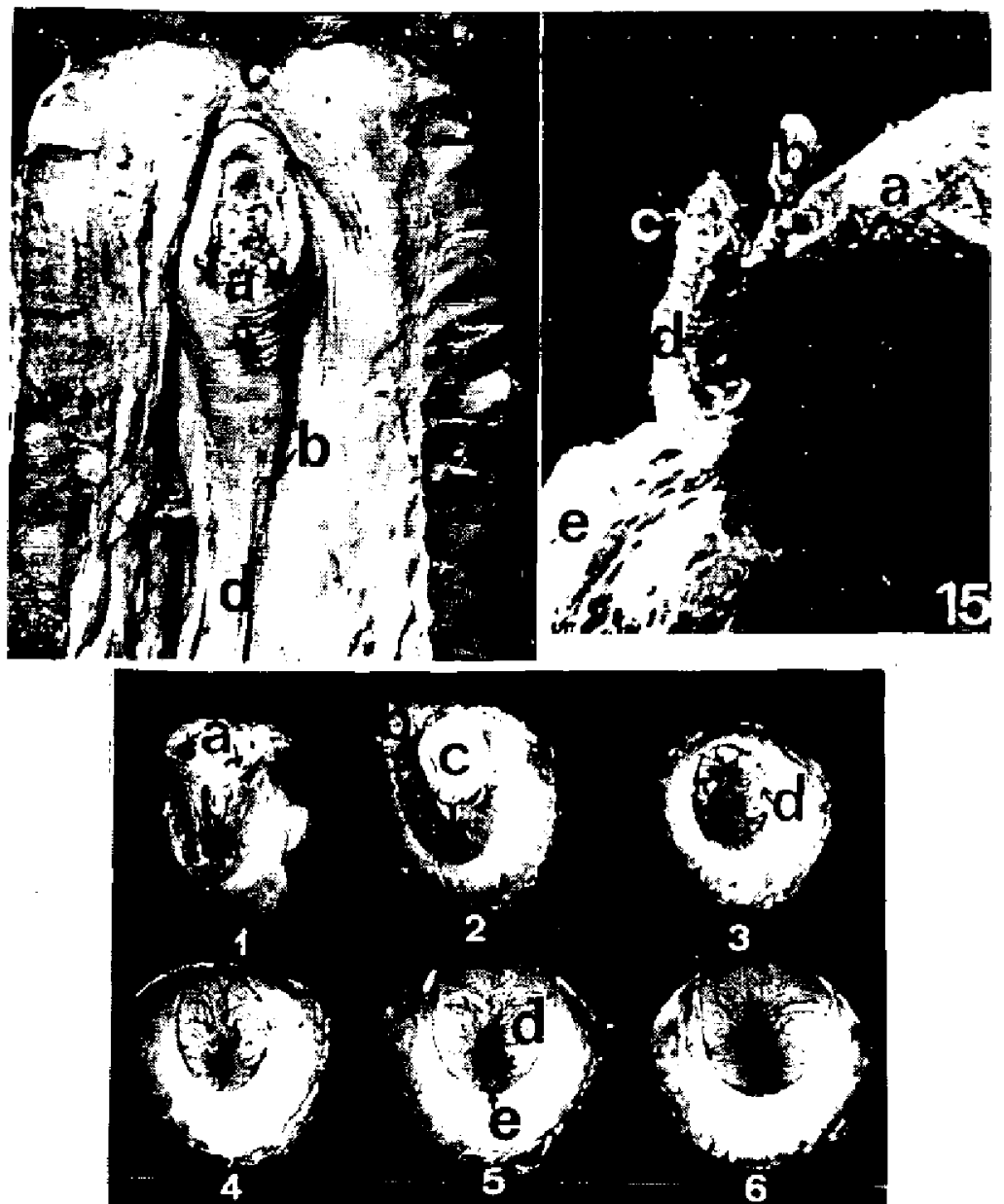

2

3
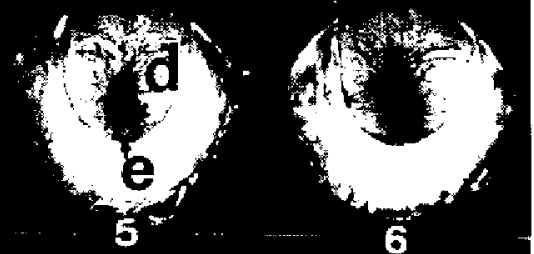

.

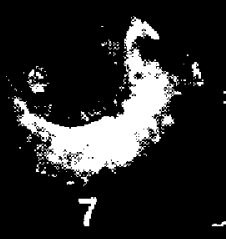

3
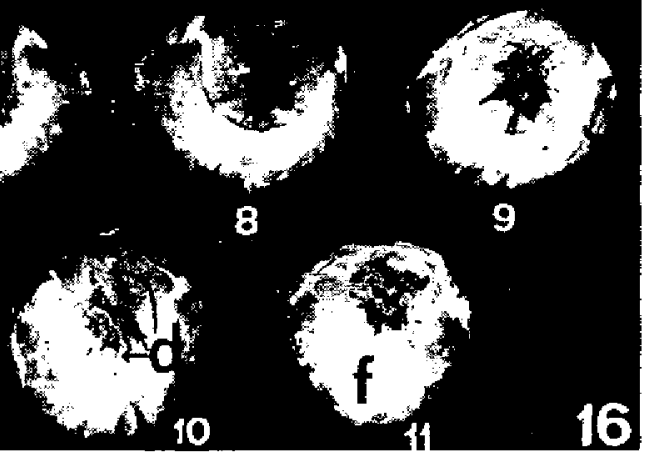

K. Swieżyński

M. Węgrzyn phot. 


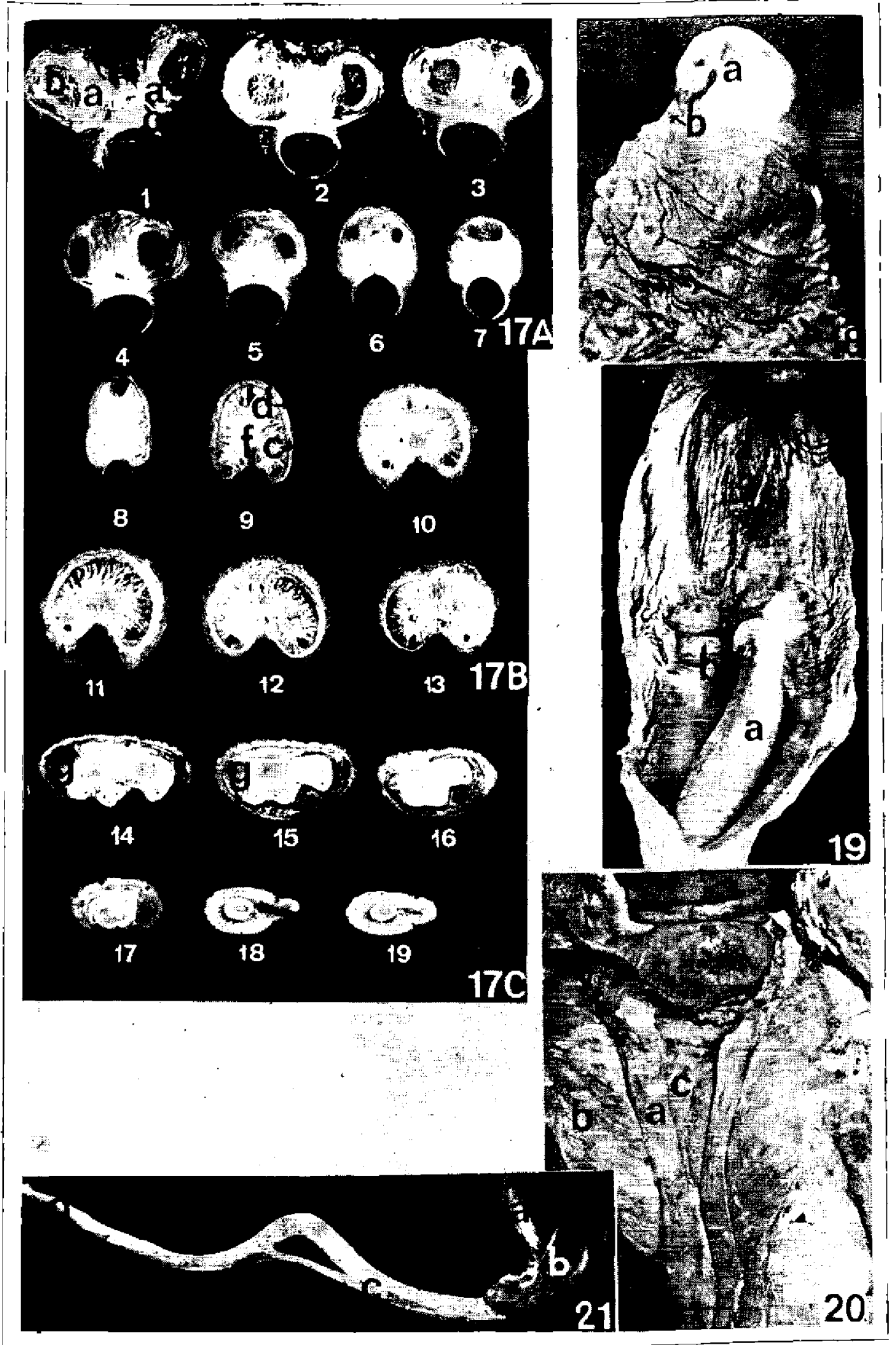

